\title{
O espírito das leis e as leis do espírito: a evolução do pensamento legislativo brasileiro em saúde mental
}

\section{he spirit of the law and the laws of the spirit: the evolution of Brazilian legal thought in the realm of mental health}

\author{
Guilherme Peres Messas \\ Unidade de Pesquisa de Álcool e Drogas (Uniad)/ \\ Universidade Federal de São Paulo (Unifesp) \\ Rua Joaquim Floriano, 871, cj.124 \\ 04534-013 - São Paulo - SP - Brasil \\ messas@netpoint.com.br
}

\begin{abstract}
MESSAS, Guilherme Peres. O espírito das leis e as leis do espírito: a evolução do pensamento legislativo brasileiro em saúde mental. História, Ciências, Saúde - Manguinhos, Rio de Janeiro, v.15, n.1, p.65-98, Jan.-Mar. 2008.

Examina a evolução das leis e normas da República brasileira relativas ao padecimento mental, demarcando três períodos. No período inicial (1890-1910), caracterizado pela introdução do tema da patologia mental no campo das preocupações do Estado, o interesse fundamental foi o reconhecimento e a preservação dos direitos dos portadores dessas patologias; nesse período, a alteração mental é entendida em termos de neuropatologia. No período de ampliação da ação estatal (1911-1945) permanecem os interesses observados no período anterior; a interpretação de adoecimento mental não sofre alterações substanciais, a despeito do alargamento de sua abrangência. No período do desenvolvimentismo brasileiro (1946-1982), marcado por uma descontinuidade em relação aos períodos anteriores, prevalece um espírito econômico-desenvolvimentista, expresso na vigorosa ampliação do parque hospitalar e amparado por um pensamento humanista de tons conservadores; mantém-se o interesse na proteção dos portadores de doenças mentais.
\end{abstract}

Palavras-chave: legislação em saúde mental; psiquiatria; psicopatologia; história; Brasil; João Carlos Teixeira Brandão; Mario Yahn.

MESSAS, Guilherme Peres. The spirit of the law and the laws of the spirit: the evolution of Brazilian legal thought in the realm of mental health História, Ciências, Saúde - Manguinhos, Rio de Janeiro, v.15, n.1, p.65-98, Jan.-Mar. 2008.

The article explores the evolution of the Brazilian republic's laws and norms on mental illness during three periods. The first (1890-1910) saw the topic of mental pathology introduced into the State's realm of interest, with the main concern being to recognize and preserve the rights of those displaying such pathologies. During this period, mental alterations were understood in terms of neuropathology. The following period (1911-1945) saw expansion of government initiatives, with the same concerns as the previous period. The interpretation of mental illness did not undergo any major changes, although it broadened in scope. Marked by a discontinuity in relation to previous times, Brazil's developmentalist period (1946-1982) saw an economic developmentalist spirit hold sway, underpinned by humanist thought of conservative propensity. It brought a vigorous growth in the number of Brazilian hospitals, while interest in protecting the mentally ill continued.

Keywords: mental health law; psychiatry; psychopathology; history; Brazil; João Carlos Teixeira Brandão; Mario Yahn. 
$\mathrm{E}$ m 6 de abril de 2001, a Presidência da República assinou a lei 10.216, acerca da saúde mental no Brasil. Essa lei representa a peça mais atual de um longo e polêmico processo histórico - distante ainda de encerrar-se -, repleto de tentativas de legislar sobre a posição social dos portadores de transtornos mentais no país. Este estudo procura abordar de uma perspectiva histórica essa discussão, traçando seus antecedentes ao longo da República brasileira.

A análise das leis brasileiras sobre a saúde mental tem, como finalidade, não o estudo da evolução do panorama sanitário republicano, mas a compreensão daquilo que, oficialmente, a sociedade brasileira imaginou como desejável para o encaminhamento das questões pertinentes ao padecimento mental. Foram excluídas desta pesquisa as publicações exclusivamente focadas em aspetos médico-legais ou criminais. Trata-se, portanto, de uma pequena contribuição à história da mentalidade sanitária republicana brasileira, ainda que, dado o caráter normatizador do ordenamento jurídico, poderíamos falar mais especificamente da mentalidade de grupos politicamente dominantes da sociedade. Foge, no entanto, ao nosso escopo perscrutar as conseqüências pragmáticas que tais idéias tiveram sobre o corpo social, no que tange a políticas públicas. Transcende igualmente o objetivo deste trabalho a investigação de conflitos sociais e interesses latentes em cada lei ou norma.

A investigação dos diplomas legais acabou por exigir um mergulho em outro ramo do estudo das mentalidades em saúde: a interpretação dada, durante as décadas em estudo, à noção de doença mental. Pareceu-me que, sem a análise dos deslocamentos de sentido concernentes à percepção dos fatos psicopatológicos, o trabalho poderia se tornar superficial, uma rala apresentação temporalmente linear de leis e normas. Porém, dado o seu caráter subsidiário para esta pesquisa, a escolha e análise dos textos, por assim dizer, reveladores das tendências de pensamento de cada época deram-se com a finalidade única de mostrar a inspiração de cada lei ou norma e como pensavam seus formuladores ou coetâneos.

Para uma exposição mais clara do tema estabeleci uma periodização destacando três etapas: um período inicial, o período da ampliação da ação estatal e o período desenvolvimentista. A divisão, arbitrária como toda fragmentação de períodos históricos, procura refletir os grandes movimentos da história sanitária brasileira (Luz, 1982). ${ }^{1}$

\section{O período inicial (1890-1910)}

No Brasil, a autonomia da assistência ao padecimento mental² é criação e obra da República. Cinqüenta e sete dias após a sua proclamação, em 11 de janeiro de 1890, ainda no calor dos acontecimentos ligados à ruptura institucional e sob a tutela do governo provisório, foi expedida a primeira de uma longa série de normas jurídicas concernentes ao campo mental, o decreto 142 (Brasil, 11 jan. 1890). A análise do período que vai desde este primeiro decreto até a Lei Teixeira Brandão, de 1903, é o objetivo deste item. A fase caracteriza-se pela constituição de um pensamento oficial relativo à assistência ao padecimento mental e pelas primeiras tentativas de organização institucional. Uma certa semelhança de perspectivas e interpretações acerca do mental patológico, da saúde como um todo e do papel do Estado em relação a ela (Luz, 1982) parecem igualmente justificar esse recorte.

O primeiro ato do nascente governo republicano, consubstanciado no decreto 142, explicita a autonomia da intervenção mental como preceito do pensamento republicano. O decreto 
"desanexa do Hospital da Santa Casa da Misericórdia desta capital o Hospício de Pedro II, que passa a denominar-se Hospício Nacional de Alienados" ${ }^{3}{ }^{3}$ A desanexação das instituições mentais daquelas de caridade em geral, assim como a ruptura administrativa com o modelo imperial até então vigente deixam claro o estatuto que a República pretendia conceder ao mental. Em substituição da misericórdia beneficente vinculada à ação caritativa religiosa (Caponi, 2000), invocava-se o poder do Estado. A troca de denominação da instituição é bastante ilustrativa: abandonava-se o nome do imperador deposto junto com o regime que o legitimava e constituíase um Hospício Nacional. A efígie do imperador amante das artes e benemérito foi rechaçada em nome da nação brasileira arregimentada na forma de Estado federativo, os Estados Unidos do Brasil. A única invariância entre as duas denominações refere-se ao termo hospício. Quer anexada a um hospital ou autônoma e independente, a instituição era entendida essencialmente como distinta daquelas que contemplavam os doentes do corpo. Porém a autonomia administrativa ou mesmo terapêutica em nada recolocam a questão das relações entre doença mental e doença corporal. A dessemelhança entre ambos os campos, experimentada no Império, mantém-se na República, que não possuía nem procurou desenvolver instrumental teórico para definições acerca do fenômeno mental patológico que fossem além dos até então vigentes (Engel, 2001; Machado et al., 1978, p.18). A mudança institucional concernia a uma ação administrativa e atingia o corpo social, mas não alterava a percepção psicopatológica. Com o decreto, iniciava-se a história propriamente dita do setor mental como instância autônoma no Brasil.

As características desse período aparecem minuciosamente nos regulamentos que seguiram o decreto 142. Três meses passados da proclamação, a 15 de fevereiro de 1890, o decreto 206 dava instruções para o funcionamento do Hospício. Seu artigo 2 introduzia uma criação institucional: "É creado o serviço de assistência medica e legal de alienados, que se regerá pelas instrucções que também com este baixam." A ambição do recém-instituído Estado republicano ia além da autonomia do Hospício em relação ao modelo imperial, ao propor o estabelecimento de uma ampla assistência médica e legal a alienados, cujas peculiaridades passo a examinar.

\section{Centralização e concretude assistenciais}

O artigo 3 das instruções era claro a respeito do modelo assistencial: "O Hospício Nacional, único em que serão permittidos doentes pensionistas, é o estabelecimento central da assistência ${ }^{4}$, por onde transitarão todos os doentes que houverem de ser admittidos nos asylos" (dec.206 Brasil, 15 fev. 1890). Identificava-se a assistência com a centralização e esta com a presença física do hospício.

O controle centralizador do hospício se daria em dois âmbitos. Em primeiro lugar, administrativamente: "Fica desde já organizada a assistência medica e legal dos alienados com o Hospício Nacional e as colonias Conde de Mesquita e de S. Bento, devendo ser annexados a estes estabelecimentos todos aquelles que, de futuro, forem instituídos a expensas do Governo na Capital Federal, destinados ao mesmo fim" (dec.206 - Brasil, 15 fev.1890). As administrações atual e futura da assistência deveriam ser mantidas sob os cuidados do Hospício e de suas colônias anexas. Identificava-se assim centralização administrativa com presença física dos estabelecimentos, pois não se tratava da criação de um órgão federal para administrar o aparato assistencial, uma instância burocrática de assistência aos alienados no sentido abstrato, passível 
portanto de expansão para toda a população. A assistência aos alienados é o Hospício e seus anexos e vice-versa, em uma relação de concretude visceral. A instituição da assistência aos alienados não é uma idéia, mas um conjunto de edifícios.

Contudo tal percepção centralizadora e concreta da assistência não pode ser creditada unicamente ao autoritarismo característico da Primeira República, ou aos conceitos com que trabalhavam então os psiquiatras. É a própria concepção de saúde, no corpo jurídico da sociedade, que deve ser investigada para melhor compreensão do fenômeno.

Nenhuma das constituições brasileiras contemplou o tema da saúde até a de 1988, que passou a considerá-la um direito social. Anteriormente, a única menção em textos constitucionais diz respeito ao direito de intervenção do Estado em casos de necessidade de controle de epidemias, o que, segundo Silva (1998, p.311-312), "tinha sentido de organização administrativa de combate às endemias e epidemias". Observe-se, no entanto, que a saúde ainda não havia sido elaborada como conceito abstrato, conditio sine qua non para que se tornasse direito e recebesse tratamento constitucional, razão por que parece constituir um anacronismo atribuir à concretude do modelo assistencial organizado pela Primeira República uma intenção unicamente controladora e normatizadora. O artigo acima demonstra, antes, uma ligação inseparável entre assistência (e, em última análise, saúde) e presença física do estabelecimento. Não há um projeto de saúde, tal qual o concebemos contemporaneamente; há um ou mais hospícios. Portanto pode ser apressado identificar essa criação legislativoinstitucional com uma política de saúde mental. Havia apenas edifícios que assistem alienados e que se ordenavam sob uma administração fortemente centralizada.

O mesmo princípio de concretude pode explicar o outro âmbito controlador do hospício: a centralização das questões sobre a presença física do alienado. O Hospício Nacional é o local "por onde transitarão todos os doentes que houverem de ser admittidos nos asylos" (dec.206 Brasil, 15 fev. 1890). O acesso à assistência médica e legal exigia dos alienados a submissão a decisões sobre seu corpo. $\mathrm{O}$ alienado devia passar necessariamente pelo controle do hospício, mesmo que neste não permanecesse. Essa dupla concretude, administrativa e corporal, presente na instalação da assistência aos alienados, reflete uma certa concepção da presença concreta do corpo, cujas principais ressonâncias se dão no conceito de psicopatologia, abordado adiante. Já em dezembro de 1890, por exemplo, ainda nos primeiros meses de vida do Hospício Nacional de Alienados, criou-se um museu anátomo-patológico, "para o desenvolvimento dos estudos referentes às moléstias mentaes e nervosas..." (dec.1.180 - Brasil, 18 dez. 1890). Essas conseqüências, entretanto, não serão examinadas agora. No momento basta destacar a centralização e a concretude como as duas características distintivas do modelo de assistência proposto pela instrução sob exame.

\section{A constituição da especificidade profissional}

Três atos reguladores das atividades de assistência médico-legal aos alienados foram expedidos entre 1890 e 1892, os decretos 206, 508 e 896 (Brasil, 15 fev. 1890; 21 jun. 1890; 29 jun. 1892). A análise das pequenas mudanças na redação de cada um permite observar a evolução das tendências administrativas. Uma delas refere-se à constituição da ação específica do médico psiquiatra e à sua importância crescente. No artigo 3 do decreto 206 prescrevia-se: “A direç̧ão dos differentes asylos será confiada a um medico, responsavel perante o Ministro 
do Interior, de quem directamente dependerá." Esse médico deveria residir no Hospício Nacional, em casa que lhe fosse destinada (art.5), estendendo-se o princípio de concretude até para a habitação do médico.

Já o regulamento seguinte, de quatro meses depois, estabelecia: "A direcção geral da Assistência será confiada a um medico de competência provada em estudos psychiatricos..." (dec.508, art.3 - Brasil, 21 jun. 1890). A psiquiatria passava a ter poder efetivo na condução da prática assistencial. O mesmo movimento que, ao desanexar o Hospício da Santa Casa de Misericórdia, deu autonomia à assistência aos transtornos mentais, atribuiu ao médico psiquiatra a condução do processo, delimitando um novo campo de atuação profissional, inclusive na esfera administrativa.

Tal inovação não deve ser entendida como um mero alçamento do médico psiquiatra à liderança administrativa da assistência, pois ainda que esse profissional tivesse ganhado papel de maior importância, havia também disposição para estabelecer todo um novo campo de atuação, o que arregimentou novas formações profissionais ou modalidades de ação. Com efeito, o decreto 791, de 1890, criou a Escola Profissional de Enfermeiros e Enfermeiras dentro do Hospício Nacional de Alienados. O curso, de dois anos, tinha intensa grade curricular, no qual constavam: " $1^{\circ}$ noções praticas de propedêutica clinica; $2^{\circ}$ noções geraes de anatomia, physiologia, hygiene hospitalar, curativos, pequena cirurgia, cuidados especiaes a certas categorias de enfermos e applicações balneotherapicas..." (dec.896, art.25, par.1 - Brasil, 29 jun. 1892). A ênfase em conhecimentos corporais (anátomo-fisiológicos) aproximava o curso da grade curricular médica e reflete a concepção de psicopatologia da época.

A aproximação entre as grades curriculares de enfermeiros e médicos refletia também a preocupação com o tratamento. De um assistencialismo beneficente, característico do período imperial, passava-se a uma atenção terapêutica, princípio orientador da especificidade profissional. O médico devia ter competência comprovada em estudos psiquiátricos. Teria, em seu auxílio, um museu anátomo-patológico para sustentá-lo na formação de suas convicções fisiopatológicas e, como conseqüência, terapêuticas. Nesse mesmo sentido, "Haverá no Hospício, como meio de tratamento dos enfermos alienados, as officinas que o diretor geral entender conveniente estabelecer..." (dec.896, art.54-Brasil, 29 jun. 1892). As oficinas eram consideradas instrumento da terapêutica, acomodavam-se ao mesmo trajeto que inspirava a intervenção médica, a de assistir e tratar os alienados. Mestres e inspetoras eram as categorias profissionais encarregadas das oficinas terapêuticas.

Médicos, enfermeiros e enfermeiras, mestres e inspetoras perfazem o conjunto profissional dos primórdios do aparato institucional de assistência aos alienados. No futuro, essas categorias acabariam por se estabelecer como autônomas. Apenas em 1881 havia sido criada, nas Faculdades de Medicina do Rio de Janeiro e da Bahia, a cadeira de Doenças Nervosas e Mentais. E somente em 1890, como vimos, a especialidade de enfermagem surgira na alienação mental. Contudo o processo de especialização profissional também pode ser abordado pelo seu reverso, pelas transformações por que passaram as categorias assistenciais mais ligadas ao período imperial.

Vimos em que a República inovou; podemos também observar o que ela abandonou. Em 1890 constavam, entre os componentes do pessoal do serviço sanitário, “... irmãs de caridade dirigidas pela superiora respectiva” (dec.508, art.18 - Brasil, 21 jun. 1890), com funções próprias, 
já que "as officinas da divisão de mulheres estarão a cargo da superiora das irmãs de caridade, auxiliada pelas irmãs que lhe estão subordinadas" (art.62). O serviço masculino já era gerenciado por funcionários laicos, porém o assistencialismo religioso egresso do Império mantinha-se intato na ala feminina. A convivência das duas tradições não resistiria ao regulamento expedido em 1892, que não fazia qualquer referência a irmãs de caridade ao definir a composição do serviço sanitário (dec.896, art.14 - Brasil, 29 jun. 1892). Por outro lado, mencionavam-se pela primeira vez os cargos de diretor e conservador do museu anátomo-patológico. Analogamente, as irmãs de caridade eram afastadas das oficinas, substituídas por uma nova categoria de profissionais laicas, as inspetoras, subordinadas à administração. Do mesmo modo, ampliavase o quadro das especialidades médicas nas instituições públicas de assistência aos alienados. Nestas, a hierarquia religiosa foi trocada pela hierarquia administrativa republicana, em um afastamento progressivo da experiência imperial que se reforçava a cada novo edito regulador e que acabou por banir em definitivo a assistência beneficente.

Hierarquia, disciplina e exterioridade

Em sua fase de constituição, a assistência mental brasileira preocupou-se muito com a hierarquia e a disciplina de seus domínios. $\mathrm{O}$ três regulamentos sob exame revelam uma atenção minuciosa nos comportamentos preceituados para cada segmento profissional, lembrando mais a rigidez de um regulamento castrense do que instruções gerais para o bom andamento de uma instituição civil.

À direção geral deviam se submeter com rigor as demais atividades. Assim, "O enfermeiromór e os mais enfermeiros são auxiliares do serviço medico e deverão cumprir exactamente as ordens que lhe forem dadas..." (dec.508, art.25 - Brasil, 21 jun. 1890). A severidade de então manifesta-se também na descrição detalhada de cada atividade. Do decreto 896, de 1892, 13 incisos descreviam a atividade cotidiana do contador e seis a do porteiro, entre as quais "receber a correspondencia e entregal-a, fechada, ao secretario ou quem o estiver substituindo" (dec.896, art.12, inc.1 - Brasil, 29 jun. 1892), "franquear a entrada aos enfermos cuja admissão estiver autorizada" (art.12, inc.2) e, a expressar mais claramente o aspecto disciplinador do regulamento, "não permittir ajuntamentos na portaria e no vestíbulo do estabelecimento e cumprir as demais determinações expressas no regimento interno" (art.12, inc.6). Sob o princípio norteador de organização, procurava-se reduzir ao máximo as iniciativas individuais estranhas à orientação regimental.

Com mais afinco, ocasiões favoráveis à criação de um ambiente diverso daquele ordenado eram claramente rechaçadas com a proibição de quaisquer ajuntamentos que oferecessem riscos ao cumprimento das normas. Ao contínuo cabia "apresentar-se para o serviço antes da hora do expediente..." (dec.508, art.13, inc.2 - Brasil, 21 jun. 1890), ao farmacêutico, "fiscalizar o serviço confiado ao official de pharmacia" e "preparar, com o maior esmero, os medicamentos" (art 21, inc.6); "aos empregados da contadoria cumpre executar, com zelo, intelligencia e promptidão, os trabalhos que lhes forem distribuídos pelo contador" (art.9); e aos candidatos à escola profissional de enfermagem exigia-se a apresentação de "attestação de bons costumes" (art.25, par.3, inc.3). O excesso de qualificações nas atividades não deixa dúvidas: o regulamento devia ordenar não apenas as ações e costumes que movimentavam o cotidiano da instituição, mas também o ânimo daqueles que os executavam. O ideal positivista republicano de 'ordem 
e progresso' era levado às últimas conseqüências, com a ordem alcançando a intimidade psíquica dos ordenados. Aquilo que, em fins do século XX, chamou-se subjetividade, a inatingível interioridade do ser, no início do mesmo século era concebido como objeto e, portanto, passível de submissão ao ordenamento moralizador (Castel, 1978).

Essa visão, que tem como matriz a exteriorização e objetivação daquilo que em dias atuais interpretamos como interior e subjetivo, revela-se ainda em outro aspecto: a preocupação freqüente com o asseio. Ao porteiro incumbia "mandar proceder... ao asseio da portaria do Hospício" (dec.508, art.12, inc.5 - Brasil, 21 jun. 1890); ao contínuo, "executar e fazer executar, por serventes ou enfermos, a limpeza e arranjo interno da contadoria" (art.13, inc.1); ao chefe do gabinete eletroterápico cumpria inventariar dos aparelhos, fazendo-os "conservar na maior limpeza e asseio" (art.17, inc.2); e ao farmacêutico, "conservar a pharmacia no melhor asseio e ordem..." (art.21, inc.2). Ordenados por seu valor de face, o comportamento e as intenções do pessoal da instituição tinham como ponto de confluência o asseio, representante mais expressivo dessa exterioridade disciplinada, obediente e moralizada. A limpeza do ambiente externo espelhava o interior de cada membro do hospício. Uma linguagem que ainda não reconhecia o interior subjetivo e que procurava ordenar o ambiente pela hierarquia disciplinadora tinha, necessariamente, na noção de asseio seu carro-chefe conceitual. Limpos, moralizados e ordenados, funcionários e enfermos poderiam cumprir as metas propostas para a assistência à alienação mental. Na base de todas essas concepções não podemos deixar de enxergar a silhueta do país recém-saído da escravidão, da pobreza e desorganização urbanas, e uma crença de que as idéias republicanas conduziriam a jovem nação à civilização. Em poucos anos surgiriam os grandes projetos higienizadores comandados por Oswaldo Cruz, a reurbanização da capital federal dirigida por Pereira Passos, a Revolta da Vacina (Pamplona, 2002).

\section{A exclusão}

$\mathrm{O}$ tema do isolamento social dos doentes mentais tornou-se relevante à medida que se problematizou a exclusão e revelou-se a sua face de estratégia de dominação social, o que só viria a ocorrer nas décadas de 1960 e 1970, sob inspiração das análises de Michel Foucault (1995). No período aqui em exame, a exclusão desempenhava papel de mero figurante na assistência ao padecimento mental. Para o legislador, ela era instrumento vicariante do tratamento: "A Assistência Medico-Legal de Alienados... tem por fim socorrer... os indivíduos... que, enfermos de alienação mental, carecerem de tratamento" (dec.896, art.1 - Brasil, 29 jun. 1892). O artigo é claro: a finalidade da instituição criada é o tratamento de alienados. Tratamento e internação não eram sinônimos: "O enfermo de alienação mental poderá ser tratado em domicilio, sempre que lhe forem subministrados os cuidados necessários" (dec.1.132, art.3 Brasil, 22 dez. 1903). O tratamento era a finalidade precípua da assistência e prescindia da exclusão, cujo critério único era o acesso aos cuidados: havendo-os satisfatoriamente, o tratamento poderia ser feito fora do ambiente institucional. Os dois artigos, tomados em conjunto, abalam a hipótese de que a assistência mental brasileira erigiu-se estritamente e desde o seu início sob o princípio de exclusão social da loucura. ${ }^{5}$ Mas outro fenômeno, em muito assemelhado a ela no que concerne à interpretação das diferenças entre os cidadãos, faz-se notar com nitidez: a desigualdade no tratamento conforme os estratos sociais. 


\section{A desigualdade}

A desigualdade entre os indivíduos era abordada abertamente nos atos reguladores do Hospício Nacional de Alienados e de suas colônias. A sociedade recém-saída da escravidão e conduzida à República manu militari reproduzia, no ambiente psiquiátrico, a hierarquia social vigente, e a ação estatal sobre o cidadão se dava conforme suas posses e origem:

Os enfermos em tratamento no Hospicio Nacional serão divididos nas seguintes categorias: - Pensionistas, comprehendendo quatro classes, cujas diárias serão de $10 \$$ na $1^{\mathrm{a}}, 5 \$$ na $2^{\mathrm{a}}, 3 \$$ na $3^{\mathrm{a}}$ e $2 \$$ na $4^{\mathrm{a}}$;

- Mantidos pelos Ministérios da Guerra, da Marinha, da Justiça e da Agricultura, ou pelos Estados;

- Gratuitos (dec.896, art.35 - Brasil, 29 jun. 1892).

Entretanto nada sustenta a hipótese de que tal diferenciação manifestava-se na esfera terapêutica. Diferentes e desiguais, os pacientes equiparavam-se na necessidade de tratamento, mas a igualdade não ia muito além disso:

Os enfermos indigentes só poderão sahir depois de restabelecidos, salvo com licença concedida pelo director geral; os pensionistas, porém, serão retirados, em qualquer tempo, pelas pessoas que tiverem requerido a admissão, e, na falta destas, pelos parentes e curadores, excepto quando se tratar de enfermos acommetidos de fórma de loucura que torne perigosa a sua permanencia em liberdade. Neste caso, precederá á sahida ordem do Ministro do Interior, ouvido o chefe de policia. (dec.896, art.33 - Brasil, 29 jun. 1892)

Se todos eram iguais no ato terapêutico, não o eram no momento da alta. O indigente permanecia no hospício até não apresentar risco algum. Não há menção à continuidade de tratamento fora do hospital, ao acompanhamento da retomada da vida em sociedade ou aos riscos de recaída - em suma, daquilo reconhecido contemporaneamente como reabilitação social. O legislador parece focar-se nos perigos que o doente representava para a ordem pública e na manutenção desta. Os indigentes, sem ter quem os protegesse e fiscalizasse, eram retidos pelo Estado; os pensionistas podiam ser retirados por responsáveis, desde que tampouco representassem perigo.

O tratamento objetivava a cura - o que permite afirmar a existência de uma psiquiatria -, e a cura visava a ordem pública. Reforça essa hipótese o fato de invocar-se o ministro do Interior, auxiliado pelo chefe de polícia, como signatário da alta do pensionista, nos casos em que ela configurava risco público. Portanto, nos casos extremos, competia à administração pública a decisão sobre o momento em que o indivíduo retornaria ao convívio social. Em última instância, a doença mental era, literalmente, caso de polícia.

Porém a diferença de tratamento não se explica unicamente pela questão da ordem pública, pois as distinções se davam não apenas nas condições de retorno do interno à sociedade, mas também nas suas relações com ela durante o internamento: "Os enfermos indigentes só poderão ser visitados, ordinariamente, no primeiro domingo de cada mez... Os pensionistas, porém, receberão seus parentes, curadores ou correspondentes duas vezes por semana..." (dec.896, art.53 - Brasil, 29 jun. 1892). Talvez o que melhor explique essa iniqüidade escancarada de direitos seja a escravidão, apenas recém-abandonada. O isolamento então prescrito para os indigentes tinha raízes em uma tradição cultural escravagista, que tratava com normalidade a 
categorização de cidadãos em superiores e inferiores, em termos de direitos. Note-se que o isolamento não era intrínseco ao modelo terapêutico, já que àqueles que pagavam reservavase o direito de uma visitação bem mais freqüente; ele era dirigido, a priori, ao pobre, identificado como responsável pelas mazelas do país (Patto, 1999).

A desigualdade assumia ainda uma outra face, também ela característica do período: a concretude. A morte dos pacientes internados cumpria procedimentos diferentes. Incumbia aos médicos "autopsiar os cadáveres que sahírem das subdivisões, salvo tratando-se de contribuintes, e entregar ao director geral as notas relativas ás autópsias..." (dec.896, art.15, par.5 - Brasil, 29 jun. 1892). Assim, na concretude de seus corpos, uma vez separados da mente que os igualara temporariamente, os indigentes tinham estatuto diverso dos pagantes. Os corpos daqueles pertenciam ao Estado, ao passo que os dos pagantes eram propriedade da família. Tal recorte soa estrangeiro às categorias conceituais contemporâneas, ancoradas na investigação da causa mortis como critério para realização de autópsia. Hoje, nosso pensamento iguala todos os corpos, queremos saber do que se morreu, mas no início do século XX também se colocava a questão: quem morreu? O reconhecimento da causa mortis (e as eventuais pesquisas que o recém-fundado museu anátomo-patológico pudesse conduzir) secundava o estatuto do paciente falecido. De certo modo, a investigação do corpo devia conferir, à solenidade da morte, uma profanação, evitada aos contribuintes e imposta aos indigentes, prováveis egressos da escravidão. Mais uma vez, é a concretude que separa cidadãos; se não mais a cor da pele, o destino final dos corpos.

\section{A proteção individual}

As análises até agora encetadas projetam um olhar dos dias de hoje aos dias de então. Tentemos, então, nos aproximar do pensamento daqueles legisladores e dar voz às suas pretensões ao proporem leis e normas.

Tal esforço leva-nos a João Carlos Teixeira Brandão, principal figura do período inicial da psiquiatra brasileira e responsável pela primeira lei considerada mais abrangente sobre assistência a alienados, o (dec.1.132 - Brasil, 22 dez. 1903). Brandão tornou-se deputado para conseguir aprová-la, e ela entrou para a história como a lei que leva seu nome. Ela seria analisada por seu autor em Elementos fundamentaes de psychiatria clinica e forense (Brandão, 1918), obra publicada no final da vida de Brandão e por ele considerada uma consolidação das teorias e doutrinas que o guiaram na sua trajetória.

Há, em primeiro lugar, que situar o ambiente cultural em que surgiu a necessidade de um projeto de lei específico para alienação mental. Um panorama desse ambiente é feito por Teixeira Brandão (1918), quando narra a situação anterior à promulgação de sua lei:

Assim não acontecia, alguns annos atraz. As autoridades públicas não tinham intervenção no Hospicio D. Pedro $2^{\circ}$. Os alienados eram enviados para o asylo de mendigos, na cidade do Rio de Janeiro, ou para as cadeias. Das antigas Províncias, apenas, tres ou quatro tinham estabelecimentos especiaes para alienados. Em regra geral, esses infelizes ficavam ao abandono, ou eram reclusos nas cadeias publicas. (p.139)

O anseio do legislador era introduzir o tema na pauta do Estado. Oscilando entre a administração religiosa do Hospício Nacional de Alienados e o encarceramento policial, a 
alienação não recebia do poder público a atenção que Brandão reclamava como justa e necessária. Brandão tencionava levar o Estado a assumi-la no âmbito da assistência à saúde propriamente dita. A ação estatal, contudo, não deveria restringir-se à atividade assistencial, pois, mesmo com a laicização e autonomia do Hospício relação à Santa Casa, "a protecção legal de que carecem, porém, esses enfermos continuava insubsistente. Não havia leis que os protegessem. A admissão nas casas de saúde particulares não obedecia a nenhum preceito legal. O patrimônio do enfermo podia ser desbaratado sem que a justiça publica disso cogitasse" (Brandão, 1918, p.144). A lei proposta e finalmente aprovada sob os auspícios de Teixeira Brandão tinha uma abrangência inaudita na história brasileira, porque procurava dar condições assistenciais e jurídicas para a proteção integral do alienado mental. Observada contra o pano de fundo da época, constituiu uma peça marcadamente progressista, atenta para a proteção do indivíduo e moderna, em certos aspectos, até mesmo para os dias de hoje.

O que convém é que a lei impeça as seqüestrações arbitrárias, que não permitta a reclusão senão depois das provas documentadas da molestia, impossibilitando dessa arte as fraudes e as violencias contra a liberdade individual sob o pretexto de uma moléstia que, na realidade, não existe.

O que compete á autoridade é ter sob sua jurisdicção todos os estabelecimentos onde houver alienados para tornar effectiva e eficaz a protecção de que carecem. E não é só isso. Quem lhes zelaria a fortuna, salvando-os á indigência, si a avidez e a cubiça não encontrassem na lei um obstáculo aos seus desígnios?

E como poderia a autoridade estender até os alienados conservados fóra dos asylos a influencia benéfica de sua protecção e acautelar-lhe os bens, si não houvesse uma providencia legislativa que, impondo a obrigação de levar ao seu conhecimento os factos ocurrentes e relativos aos alienados, lhe permittisse fiscalizar e intervir quando julgar necessário? (Brandão, 1918, p.147)

No trecho encontramos muitos dos argumentos de nossos contemporâneos: o necessário impedimento a internações injustificadas e ilegítimas; a proteção contra a cobiça daqueles (família ou instituições de tratamento) que se utilizam da doença para finalidades estritamente econômicas; a atenção abrangente aos doentes; a fiscalização e intervenção estatal diante de irregularidades.

Observemos ainda esta passagem:

E, estando provado pelos estudos os mais minuciosos, pelas estatisticas as mais dignas de fé que as molestias mentaes são tanto mais curáveis quanto mais cedo são tratadas, não é curial que, si não por intuitos humanitários ao menos pelo interesse economico o Estado intervenha promovendo a applicação do tratamento e garantindo os bens dos alienados? (Brandão, 1918, p.158)

Conhecedor da fragilidade de um apelo humanitário, Brandão já invocava então o argumento econômico. Não seria a essa linha que a Organização Mundial de Saúde (OMS, 2001) recorre hoje, para evidenciar o flagelo econômico que os transtornos mentais dos indivíduos representam para a sociedade?

Em resumo, toda a série de argumentos de Teixeira Brandão, na defesa da lei de sua autoria, parece seguir viva e relevante um século após sua sustentação primeira. Também atuais, ainda que em linguagem de época, eram os "intuitos do legislador": "acautelar os bens dos alienados...; 
impedir as sequestrações arbitrárias, submettendo á fiscalização do procurador da República... e de um medico especialista..." (Brandão, 1918, p.167). Inspirava-se o autor nos princípios de "liberdade individual, de protecção dos alienados e garantidores de seus bens" (p.159), ao propor a ação sobre a alienação mental como competência do Estado.

Prescrevia ainda a lei:

a reclusão... só se tornará effectiva em estabelecimento dessa espécie, quer publico, quer particular, depois de provada a alienação.

Se a ordem publica exigir a internação de um alienado, será provisória sua admissão em asylo publico ou particular, devendo o director do estabelecimento, dentro em 24 horas, communicar ao juiz competente a admissão do enfermo e relatar-lhe todo o ocorrido a respeito, instruindo o relatorio com a observação medica que houver falta" (dec.1.132, 22 dez. 1903, citado em Brandão, 1918, p.162).

A doença precisava ser comprovada do ponto de vista médico e protegida legalmente, conforme uma concepção social da função terapêutica que se assemelha às mais fecundas preocupações contemporâneas com os direitos humanos.

Ainda que fosse concisa sobre o modelo assistencial, a lei não afirmava peremptoriamente qualquer primazia assistencial: "O enfermo de alienação mental poderá ser tratado em domicilio, sempre que lhe forem subministrados os cuidados necessários" (dec.1.132, 22 dez. 1903, citado em Brandão, 1918, p.163). O legislador preocupava-se apenas com a qualidade da assistência, e não com a modalidade dela. Exigia, contudo, a especificidade de função assistencial, pois o artigo 10 do decreto proibia "manter alienados em cadeias publicas ou entre criminosos" (p.163). O interesse pela qualidade expressava-se também na regulamentação dos serviços destinados à assistência. O artigo 13 prescrevia: “Todo hospicio, asylo ou casa de saúde, destinado a enfermos de moléstias mentaes deverá... ser dirigido por profissional devidamente habilitado e residente no estabelecimento [par.1]; installar-se e funccionar em edifício adequado, situado em logar saudável... [par.2]; possuir compartimentos especiaes para evitar a promiscuidade de sexos... [par.3]" (p.164).

Assim era a primeira lei abrangente sobre a saúde mental no Brasil, declaradamente defensora dos direitos individuais e muito semelhante às legislações atuais, ao contrário dos regulamentos que a precederam. No entanto tais afastamentos e aproximações, se analisados superficialmente, podem conduzir a conclusões equivocadas. Um grande erro consistiria em considerar que a noção de psicopatologia teve o mesmo significado ao longo do tempo, ou seja, que ela expressa hoje exatamente o que expressava, por exemplo, para Teixeira Brandão no início do século $\mathrm{XX}$. Veremos que, a despeito das aparentes semelhanças, tanto a definição quanto a abrangência da psicopatologia guardam diferenças consideráveis quando comparamos o período inicial da psiquiatria brasileira com os dias atuais.

\section{A psicopatologia em Teixeira Brandão}

Como vimos anteriormente, depreende-se uma certa compreensão de realidade marcada pela concretude e exterioridade. O modelo de assistência proposto tem como elemento central o edifício do hospício, e as normas prescrevem um código minucioso de conduta aos funcionários, que procura até mesmo ingerir-se nas suas motivações psicológicas. Veremos 
agora como essa apreensão da realidade administrativa e legal assemelha-se à concepção de psicopatologia para Teixeira Brandão, por meio do destaque de alguns aspectos.

\section{A posição da psiquiatria}

Logo na abertura de seu livro, Teixeira Brandão (1918, p.15) situa a psiquiatria como um ramo da neuropatologia. E ainda que advirta, adiante, que não se deve identificar a psiquiatria à patologia nervosa - "a psychiatria não pode subordinar-se ao methodo que a neuropathologia emprega no estudo dos phenomenos morbidos" (p.16) - observa-se uma clara relação de subordinação entre a primeira e a segunda noções. Isso se deve ao fato de que, na época, a patologia praticamente identificava-se à neurologia. De fato, na obra de Teixeira Brandão a psicopatologia ainda não é entendida conforme a sua concepção moderna ${ }^{6}$, ou seja, uma ciência autônoma do fato psicopatológico individual que, uma vez identificado, leva ao interesse por suas origens e causas, sejam elas cerebrais, psicodinâmicas ou sociais. A psiquiatria de Teixeira Brandão interessa-se pelos desvios funcionais do cérebro, cujo estudo remete diretamente à existência concreta, no cérebro, de fatos patológicos.

Tal postura metodológica não deve ser compreendida como um mero associacionismo à moda Gall, já em desuso no início do século XX. Brandão (1918, p.22) admite que "o que caracterisa a affecção psychica é a perda da harmonia funcional, das relações que entre si guardam a subjectividade e a objectividade...". Porém ao ser qualificada como funcional, essa 'harmonia' aproxima-se menos do psiquismo subjetivo, do equilíbrio de suas experiências conscientes e mais de um equilíbrio neurológico. Para Brandão, o que caracteriza a "afecção psíquica" é uma alteração nas relações do "eu consciente e o meio, de maneira que alterada aquela harmonia ou perturbado o equilíbrio physiologico, os estímulos externos não são mais percebidos como eram anteriormente de conformidade com o habito e a experiência adquirida" (p.22).

Brandão procura dotar a psiquiatria de um estatuto de autonomia, mas não desenvolve uma noção, sequer tácita, de psicopatologia como ciência autônoma. Desprovida dessa condição, sua psiquiatria não consegue separar-se definitivamente da neurologia, tendo que ser apresentada como um ramo da neuropatologia. No espírito de concretude que instruía a época, uma psicopatologia autônoma seria algo demasiadamente etéreo e incorpóreo. Dito em outras palavras, em meio ao positivismo então em vigor no país, não havia como se criar uma psicopatologia do subjetivo.

\section{A psicopatologia propriamente dita}

Embora não houvesse ainda uma psicopatologia autônoma, sobretudo no que concerne ao estudo minucioso das singularidades subjetivas, operava-se um dado reconhecimento e uma catalogação da patologia mental que podem, com alguma dose de anacronismo, ser designados como psicopatologia. Investiguemos as características dessa psicopatologia segundo Brandão, em uma breve sistematização dos seus achados.

Padrão exterior de definição

Os comportamentos alterados apresentam-se sob múltiplas formas, deixando atônito aquele que procura identificar a doença. A esse respeito, Brandão (1918, p.26) propõe: 
Com effeito é na conducta que, scientificamente considerada, traduz a conformidade ou o ajustamento do individuo ao meio, que encontraremos o critério seguro para o diagnostico do caso clinico. Por maior que seja a desordem real ou apparente do espírito, se os actos não se afastam da norma geral, o individuo não pode ser considerado alienado; assim como, se os actos não são conformes á conservação do individuo ou as suas relações com o meio social, não obstante a apparencia de integridade mental, como alienado deve ser tido.

Nesse trecho explicita-se a característica de exterioridade radical da psicopatologia em Brandão. Apenas aquilo que é exterior (mais precisamente, relacionado ao meio) sustenta a condição psicopatológica, uma alteração do equilíbrio entre a pessoa e o meio. Tudo mais são aparências sujeitas a mistificações e indignas de figurarem como ponto de apoio diagnóstico ao psiquiatra. O comportamento é que deve ser cientificamente considerado, e apenas ele pode ser estudado do mesmo modo. A ciência psiquiátrica é aquela que estuda atos e comportamentos: "é pelo estudo e pela investigação dos actos em relação as causas efficientes delles... que poderemos chegar a uma conclusão científica" (Brandão, 1918, p.26).

\section{A hereditariedade como degeneração: influências essenciais}

Uma psicopatologia desapegada à vivência subjetiva e definida segundo perfis de adaptação social não poderia contemplar a hereditariedade tal como vêm fazendo, nas últimas quatro décadas, os estudos genéticos. A ausência desse olhar da experiência subjetiva deixa a concepção de hereditariedade vulnerável às teses darwinistas, que tiveram em Morel sua principal expressão psiquiátrica. Em Brandão, a hereditariedade tem um ponto de contato estreito com a teoria da degeneração, e a ciência é empregada para sustentar a diferença entre os seres humanos, cindindo-os entre superiores e inferiores.

Sem qualquer base estatística, o autor afirma: "se exceptuarmos a hereditariedade mórbida, a predisposição congenita e adquirida, cuja evidencia é manifesta, todos os phenomenos physicos, physiologicos, pathologicos, e sociaes aos quaes se tem attribuido o papel de factores etiológicos representam sempre um papel secundário ou meramente accidental" (Brandão, 1918, p.36). A evidência supostamente "manifesta" é a prova de que a hereditaridedade é o aspecto essencial nas causas da patologia mental.

A aproximação entre hereditariedade e degeneração leva o autor a conclusões que só podem ser entendidas a partir de uma lógica que ainda não havia incorporado (ou inventado) a categoria 'desenvolvimento subjetivo'. A hereditariedade mórbida é entendida ab initio, um germe degenerado que não conseguirá seguir outra trajetória senão aquela traçada originalmente, apesar das influências do meio. A própria degeneração, para o espírito da época, é reconhecível por seus signos exteriores e concretos:

assim como a desharmonia e assymetria das formas, a magreza excessiva, a macilencia, o olhar aparvalhado, duro e esquivo, a obesidade, etc. são indicios de estados regressivos, possiveis vestígios de processos mórbidos anteriores, de relativa importância, entretanto, em todos os casos de alienação por isso que constituem indícios vehementes de desvios ou de perturbações da evolução normal, por causa hereditária. (Brandão, 1918, p.64)

Somente considerando a estrutura de pensamento da primeira década do século XX podemos entender esse autor que se lança obstinadamente na promulgação de uma lei de ampla defesa de direitos individuais de doentes mentais, ao mesmo tempo que afirma: "Em nosso conceito, 
a sociedade em bem da sua propria conservação, e como recurso preventivo contra ônus futuros, deveria impedir a propagação, tanto quanto possivel dos degenerados..." (Brandão, 1918, p.32). Sabemos hoje aonde tais idéias nos levaram, com seu ápice durante a Segunda Guerra Mundial.

\section{O princípio da classificação}

Teixeira Brandão desenvolve sua própria classificação das afecções mentais. Em uma época em que a hegemonia da taxonomia de Kraepelin ${ }^{7}$ já se fazia sentir em todo o mundo. Brandão ousava opor-se ao pensamento krapeliniano, censurando-o por ter englobado "sob a mesma designação casos pathologicos heterogeneos, tornado-a dessa arte [a classificação] imprópria e inadequada" (Brandão, 1918, p.103). Tal discordância, contudo, não implica seu afastamento de uma concepção neurológica, na formulação das categorias: “Com effeito, com exceção dos casos em que correspondem a uma perturbação dynamica por intenso abalo emotivo, as desordens mentaes dimanam de uma lesão primitiva ou secundaria do cérebro, sendo dellas syndromas: ou dependem de um vicio originario do mesmo orgão no momento da sua evolução" (p.93). Brandão admite a ocorrência do que denominamos quadros reativos, causados por intenso abalo emotivo, porém como exceção que confirma a regra 'a afecção mental é afecção do cérebro'. Com base nela, analisa e ordena o que entende por doenças mentais alienantes. Note-se que a noção de psicose reativa ainda não havia sido incorporada na seara das psicoses, nem portanto no campo da medicina mental. Contemporaneamente ao autor, em 1913, Jaspers introduziu essa noção, classificando-a no mesmo nível heurístico dos processos patológicos (de provável origem biológica) e de desenvolvimento da personalidade (ligados às tendências constitucionais). Ou seja, a partir de Jaspers as reações psicológicas passaram a integrar a psicopatologia geral.

Brandão classifica as afecções mentais em dois grandes grupos, conforme o nível de completude do desenvolvimento cerebral. No primeiro deles "o desvio evolutivo não foi de molde a tolher a expansão e o desenvolvimento mental que operou-se sem comtudo atingir a harmonia funccional indispensável á conducta e permanencia no meio social, sem infraç̧ão das suas leis" (Brandão, 1918, p.93). No segundo, o desvio evolutivo cerebral "foi tão anômalo que não permittio senão um desenvolvimento rudimentar, incompatível com o conhecimento e acquisição dos mais elementares deveres que a convivência acarreta" (p.93). Esses grupos dividem-se em subcategorias. No primeiro grupo, composto por aqueles que se desenvolveram normalmente e foram acometidos posteriormente pela patologia, incluem-se as psicoses, as cerebro-psicoses e as cerebropatias. No segundo grupo, daqueles que não conseguiram se desenvolver adequadamente, situam-se as degenerações.

Não nos cabe apresentar em detalhes as definições propostas para cada categoria. Para os propósitos deste trabalho, basta destacar o princípio que inspira a classificação, o qual poderia ser assim sintetizado: quanto mais passível de definição em termos cerebrais, mais descritível a afecção, mais clara a demarcação das fronteiras categoriais. Com isso não quero dizer que a única preocupação do autor fosse a investigação da base cerebral patológica; no inventário de cada classe de doença existe, efetivamente, lugar para a sua apresentação clínica. Contudo o detalhamento desta é inversamente proporcional aos dados cerebrais disponíveis: quando eles não estão acessíveis, a descrição clínica é extensa; quando a participação cerebral é mais bem compreendida, praticamente não há descrição clínica. Assim, por exemplo, nesta passagem: 
nas psychoses, a desagregação da personalidade ou effectua-se lenta e uniformemente de modo que ao irromper a affecção os elementos, que a compõe, aparecem desde logo desordenados na esphera intelectual e moral; ou essa desagregação vae-se operando progressivamente á custa das alterações parcelladas dos centros perceptivos corticaes e a pouco e pouco vae-se também esboçando o delirio (p.105),

a descrição clínica antecede a da atividade cerebral, definida com base na hipótese de centros perceptivos corticais. Diversamente, no trecho

Nas cerebro-psychoses começam a aparecer as alterações da estructura orgânica. As cellulas cerebraes e em certos casos todo o tecido neuro-epithelial podem ser compromettidos. Conforme a intensidade dos momentos etiológicos - intoxicações endogenas e exogenas e infecções - o estado mental póde ir do simples torpor á exaggerada excitação com predominio das illusões e das allucinações que se alternam... (p.105),

predominam os aspectos neuropatológicos, os únicos a compor a descrição das cerebropatias:

as lesões estructuraes são mais profundas: podem começar pelo tecido vasculo-conjuntivo e invadir o neuro-epithelial ou começar por este invadindo aquelle em seguida. A arterioesclerose, a demencia senil, a demencia primitiva e secundaria, a meningo-peri-encephalite diffusa, as neoplasias e necrobiose cerebral completam esse grupo" (p.106).

A elaboração de categorias científicas determina as ferramentas com que se conseguirá ordenar a realidade e sobre ela agir. Na obra em questão, entende-se como alienação tudo aquilo que pode ser traduzido ou reduzido a termos cerebrais, tendo como limite as psicoses, nas quais se infere a participação cerebral sem contudo prová-la com clareza. A psiquiatria em Teixeira Brandão encontra-se no campo da patologia cerebral, e tudo aquilo que dela se afasta em demasia - seja pela menor gravidade ou pela impossibilidade de explicá-lo em termos cerebrais - não é objeto dessa ciência e práxis. Há, portanto, uma considerável diferença entre o período sob exame e a época atual. A psiquiatria contemporânea ocupa-se de uma extensão de fenômenos muito mais ampla do que imaginara aquele autor, e lança mão de diferentes lentes conceituais para conferir lógica às suas construções heurísticas.

\section{A estreiteza da abrangência}

Para Teixeira Brandão, a abrangência do campo da psiquiatria era francamente menor do que almeja a psiquiatria contemporânea, para quem as categorias do autor contemplam apenas quadros clínicos de maior gravidade e menor proporção epidemiológica. Contudo, mesmo para a sua época, a reduzida abrangência classificatória exigiu justificativa. Nas últimas linhas do capítulo sobre classificação, Brandão (1918, p.108, 109) dialoga com seus contemporâneos:

Não deve causar extranhesa a quem tiver comprehendido o espirito dessa classificação e das idéas expedidas nesse trabalho não ver destacadas dentre as formas de perturbações mentaes as chamadas: neurasthenia e psychastenia.

Tanto uma como outra não constituem em nosso conceito modalidades morbidas.

São apenas expressões symptomaticas de estados constitucionais cuja descripção acabamos de fazer.

Assim tambem as formas denominadas erroneamente - loucura hysterica, loucura epiléptica, loucura choreica. 
O delirio, muitas vezes observados nessas nevroses, é dellas uma manifestação symptomatica, um equivalente morbido, ou com ellas coexiste, como rebento do mesmo tronco.

Os delirios secundarios (paranóias secundarias de alguns autores allemães) são apenas residuos ou vestigios que ficaram do incêndio anterior.

O autor prevê que sua lógica restrita não passará despercebida para o leitor atento e esclarece que as neuroses, e mesmo os quadros deliróides, não constam de sua classificação por não serem doenças. E é sobre esse pano de fundo, essa compressão da psiquiatria a um número mínimo de patologias que devemos entender as primeiras formulações legais abrangentes, no país, acerca dos doentes mentais.

\section{O período da ampliação da ação estatal (1911-1945)}

No primeiro item deste trabalho analiso as condições em que surgiu a primeira legislação em saúde mental na República brasileira. Este item dedica-se à etapa seguinte, cujas peculiaridades permitem caracterizá-la como a fase de ampliação da ação estatal. Assiste-se à ascensão do pensamento antiliberal (Skidmore, 1998) e, sobretudo a partir de 1920, às ações autoritárias e intervencionistas no campo da saúde (Luz, 1982).

A partir da Lei Teixeira Brandão, seguiu-se uma cadeia de atos normativos que tinham em comum o propósito de ampliar a ação estatal sobre a saúde mental da população. No período anterior havia uma composição equilibrada de interesses, no que concerne à defesa dos direitos individuais dos alienados e à ação do Estado como gerente das instituições assistenciais. No período agora em análise esse equilíbrio parece se romper, passando a vigorar um crescente predomínio da intervenção estatal.

Ressalte-se que a nova orientação pouco transformou a compreensão de psicopatologia: a série de prescrições, encerrada com o decreto 24.559 , de 1934, inspirou-se fundamentalmente nas concepções formuladas por Teixeira Brandão. Houve, entretanto, uma radicalização nos conceitos. Portocarrero (2002) defende que a principal característica da obra de Juliano Moreira, o mais eminente psiquiatra da época, foi o alargamento do conceito de saúde mental, que passou a reunir, além dos alienados, um amplo grupo de indivíduos chamados imprecisamente de psicopatas. Estes incluíam alcoolistas, sifilíticos e epiléticos, diagnosticados não mais pela alteração da vivência de realidade, mas com base em desvios comportamentais aferidos em relação a uma norma média (Canguilhem, 1990). Assim conclui Portocarrero (p.108), a respeito das conseqüências pragmáticas dessa interpretação de psicopatologia: "A principal característica do novo sistema de assistência é não mais se restringir ao espaço asilar, centro fundamental da psiquiatria até a época de Teixeira Brandão, mas estendê-la a outras instâncias da sociedade". É esse movimento que acompanharemos nas linhas que seguem.

A continuidade na orientação conceitual em relação ao período anterior permite-nos abrir mão de esmiuçar todas as normas expedidas nessas três décadas e optar pela abordagem daquelas que introduziram algum elemento novo.

Em 1911, a assistência aos alienados reorganizou-se através do decreto 8.834, praticamente idêntico aos regulamentos anteriores, porém com uma única e relevante novidade. Já no artigo 2, parágrafo 2, prescrevia: "Logo que possivel fundará a União colonias para ebrios 
habituaes e epilepticos". Após 1911, a agenda de saúde do país passou a incluir o tema substâncias químicas. Em 1914, por meio do decreto 2.861, ratificaram-se as resoluções aprovadas em 1911 pela Conferência Internacional de Ópio, em Haia, visando a "impedir o abuso crescente do opio, da morphina e seus derivados, bem como da cocaina...". Ainda que incipiente e genericamente, a presença do tema na legislação atesta o interesse crescente do Estado pela seara do comportamento humano.

Contudo, apenas em 1920 seria estabelecida com clareza a ampliação da ação estatal sobre a população (Pereira Neto, 2001). O marco legislativo desse novo regime nas relações entre Estado e indivíduo é o decreto 3.987, de 2 de janeiro de 1920. Por meio dele criou-se o Departartamento Nacional de Saúde Pública (DNSP), subordinado ao ministro da Justiça e Negócios Interiores. Entre as atribuições do novo órgão, figuravam:

a) os serviços de hygiene no Districto Federal que deverão abranger a prophylaxia geral e especifica das doenças transmissiveis, a execução de providencias de natureza, aggressiva ou defensiva, as que tiverem por fim a hygiene domiciliaria, a policia sanitaria das habitações privadas e collectivas, das fabricas, das officinas, dos collegios, dos estabelecimentos commerciaes e industriaes, dos hospitaes, casas de saude, maternidade, matadouros, mercados, logares ou logradouros publicos, hoteis, restaurantes e a fiscalização dos generos alimenticios. (dec.3.987 - Brasil, 2 jan. 1920)

A criação do DNSP instaurou oficialmente a intervenção do Estado pela ação policial sobre o espaço coletivo e individual. A partir de então, os objetivos higienistas e de profilaxia estatais passaram a sobrepor-se, oficialmente, aos direitos individuais. A fiscalização policial era de amplo espectro, compreendendo desde a intimidade das habitações aos espaços industriais e comerciais. Em substituição ao liberalismo do início da República no país, começava-se a desenhar um intervencionismo ditatorial.

O ato legal de criação do DNSP passou ao largo da assistência sanitária mental. Não há qualquer referência ao tema em seus dezesseis artigos, que enfatizam questões de profilaxia e higiene relacionadas a doenças infecto-contagiosas. De todo modo, o espírito intervencionista estatal, que vigoraria também nas ações relativas à saúde mental, estava lançado e sustentado juridicamente.

Tomemos, por exemplo, o caput do decreto 4.294, de 6 de julho de 1921, que já mescla penalidade e tratamento: "Estabelece penalidades para contraventores na venda de cocaina, opio, morphina e seus derivados... [e] crea um estabelecimento especial para internação dos intoxicados pelo alcool ou substancias venenosas...". A noção de tratamento é extraída da idéia de penalidade, a ela se submete - submissão esta que, mesmo na época contemporânea, temos dificuldade de nos livrar. É portanto da lógica da punibilidade que surge o tema do tratamento.

O primeiro artigo do mesmo decreto 4.294 dispunha sobre penas que iam de multas ao encarceramento por quatro anos para quem vendesse, expusesse à venda ou administrasse sem autorização substâncias venenosas. O segundo tratava das punições por comportamentos inadequados: "Apresentar-se publicamente em estado de embriaguez que cause escandalo, desordem ou ponha em risco a segurança propria ou alheia: pena: multa de $20 \$$ a $200 \$$. O dobro em cada reincidência". A interpretação principal acerca dos fenômenos relacionados às substâncias é a comportamental, naquilo que esta tem de geradora de desordem. O 'escândalo' 
tem o mesmo valor que as ameaças à segurança a si e ao outro. Mas é no terceiro artigo que o espírito intervencionista aparece com maior nitidez: "Embriagar-se por habito, de tal modo que por actos inequivocos se torne nocivo ou perigoso a Si proprio, a outrem, ou á ordem publica: Pena: internação por tres mezes a um anno em estabelecimento correccional adequado". A preocupação estatal não se centrava no tratamento propriamente dito. Reduzido a uma das modalidades da punição, tornava-se compulsório, a ser cumprido em um estabelecimento de correção. Era a correção que o legislador visava; o tratamento nada mais era do que um de seus (rígidos) instrumentos.

Para a execução da pena, o governo federal deveria criar, no Distrito Federal, "um estabelecimento especial, com tratamento medico e regimen de trabalho, tendo duas secções: uma de internandos judiciarios e outra de internandos voluntarios" (dec.4.294, art.6 - Brasil, 6 jul. 1921). Na seção de internados judiciários deveriam ficar os punidos pelo artigo 3 do decreto, e na seção de voluntários ficariam os intoxicados que comprovassem a "necessidade de um tratamento adequado e os que, a requerimento da pessoa da familia, forem considerados nas mesmas condições, sendo evidente a urgencia da internação, para evitar a pratica de actos criminosos ou a completa perdição moral" (art.6, par.2). A associação entre criminalidade, ordem pública e tratamento é estreita, todas parecem ser unicamente as várias faces de um bloco de prescrições cuja finalidade é a intervenção higienista sobre a sociedade. Nesse sentido, as primeiras formulações normativas sobre drogas diferem daquelas efetivadas para o campo da alienação. Ainda que todas tivessem se inspirado em uma mesma filosofia de cores positivistas, as normas promulgadas para o campo das substâncias químicas aproximavam-se muito mais de preocupações higienistas e criminais, ao passo que, para os alienados, havia maior atenção à salvaguarda de seus direitos individuais.

O decreto também criava um sanatório para os dependentes químicos: "Fica creado no Districto Federal, sob a denominação de - Sanatorio para toxicomanos - um estabelecimento para ministrar tratamento medico e correcional, pelo trabalho, aos intoxicados pelo alcool ou substancias inebriantes ou entorpecentes" (dec.4.294, art.9 - Brasil, 6 jul. 1921). O tratamento se fundamentava no isolamento do doente, mediante a instalação de um sanatório, e no trabalho 'correcional', princípios assemelhados àqueles que fundamentavam o tratamento de alienados, com especial ênfase ao meio físico na concepção de seus tratamentos ou correções.

A noção de profilaxia mental derivou diretamente das noções de hereditariedade, mencionadas anteriormente, e ambas tiveram como viés político propostas de intervenções eugênicas sobre a sociedade. Não é do escopo deste trabalho aprofundar a análise das posições tomadas pelo Estado brasileiro, no período, em relação à eugenia. ${ }^{8}$ Cabe, porém, salientar a importância delas para a firma de dois decretos, em 1923, considerando de utilidade pública a Liga Nacional Contra o Alcoolismo e a Liga Brasileira de Higiene Mental (respectivamente, dec.4.665 e 4.778 - Brasil, 24 jan. 1923; 27 dez. 1923) - ambos enfrentavam seus devidos temas com estratégias francamente eugênicas (Costa, 19899).

$\mathrm{O}$ auge do higienismo eugênico na legislação brasileira, entretanto, ainda estaria por vir. Antes de encontrar espaço legal para a eugenia no processo de intervenção estatal sobre os direitos individuais, o legislador em saúde mental procurou ampliar as fronteiras da assistência mental. O decreto 5.148, de 10 de janeiro de 1927 renomeou a Assistência aos Alienados, designando-a Assistência a Psicopatas. Dois alargamentos no perímetro de ação do Estado 
podem ser detectados, em relação às organizações anteriores da assistência. O primeiro referese à inclusão da auto e hetero-agressividade entre os motivos para internação. Assim, além daqueles que perturbavam a ordem e ofendiam a moral pública, também seria recolhida a estabelecimento apropriado para tratamento "a pessoa que, em consequencia de doença mental, congenita ou adquirida, attentar contra a propria vida ou a de outrem..." (art.1). De modo algum o legislador deixava de se preocupar com a ordem pública, porém a inclusão das tentativas de suicídio e homicídios de origem psicopatológica no rol dos casos sujeitos a tratamento pode ser vista como uma ação progressista, uma vez que se incorporava ao campo da saúde mental o que antes era circunscrito ao direito penal.

O segundo ponto de alargamento do escopo da saúde mental concerne à definição dos pacientes que ficariam sob a égide da recém-criada Assistência a Psicopatas: "Si a ordem publica exigir a admissão urgente de um psychopatha, alienado ou não..." (dec.5.148, art.1, par.2 Brasil, 10 jan. 1927); "o psychopatha, alienado ou não, poderá ser tratado em domicilio proprio ou de outrem..." (art.2). Embora não defina com clareza a terminologia que adota, ela sugere que não somente as formas mais graves de patologia mental seriam contempladas pela Assistência a Psicopatas, como vimos acima.

\section{O decreto 24.559, de 3 de julho de 1934}

Último ato legislativo do período em estudo, o decreto 24.559 foi, de certo modo, a peça do direito no campo da saúde mental a resistir por mais tempo, pois só seria renovada com a mencionada lei de 6 de abril de 2001. Sua reputação de maior expoente do higienismo eugênico na legislação brasileira deve ser vista com reservas. Em momento algum da história brasileira houve um higienismo eugênico radical - e aspectos positivos da nossa cultura, como este, devem se manter vivos em nossa consciência. Nenhuma lei decretada pelo Estado brasileiro ou chancelada por alguma câmara legislativa do país levou o higienismo eugênico a extremos atingidos, por exemplo, em alguns estados norte-americanos, que chegaram a esterilizar doentes mentais com finalidades eugênicas (Gould, 1985), e tampouco praticou-se o assassinato de doentes mentais, como na experiência da barbárie nazista (Ternon, 1976). Essa peculiaridade brasileira, de um eugenismo brando, mais relacionado a interesses de proteção e terapêutica, aparece no decreto em questão.

A Assistência a Psicopatas e Profilaxia Mental terá por fim:

a) proporcionar aos psicopatas tratamento e proteção legal;

b) dar amparo médico e social, não só aos predispostos a doenças mentais como também aos egressos dos estabelecimentos psiquiátricos;

c) concorrer para a realização da higiêne psíquica em geral e da profilaxia das psicopatias em especial. (dec.24.559, art.1 - Brasil, 3 jul. 1934)

A finalidade precípua do decreto 24.559 era o amplo tratamento e amparo para a população com transtorno mental, como o demonstra o título "Da proteção á pessoa e bens dos psicopatas", com oito artigos. Nele detalham-se não somente os mecanismos de proteção ao psicopata em relação a bens, direitos civis e amparo social, como também as condições de credenciamento de profissionais (art.5) e instituições atinentes à saúde mental (art.6, 7), além das formalidades a serem cumpridas na internação (art.11-19). A cuidadosa atenção a esses 
temas contrasta com a concisão com que é tratada a profilaxia mental, que, embora figure no caput do decreto, é contemplada com apenas um artigo:

O serviço de profilaxia mental destina-se a concorrer para a realização da profilaxia das doenças nervosas e mentais, promovendo o estudo das causas destas doenças no Brasil, e organizando-se como centro especializado da vulgarização e aplicação dos preceitos de higiene preventiva.

$\S 1^{\circ}$ - Para segurança dessas finalidades, o Govêrno providenciará no sentido de serem submetidos a exame de sanidade os estrangeiros que se destinarem a qualquer parte do território nacional, e os que requerem naturalização, sendo que, nêste caso, o exame deverá precisar, especialmente, o estado neuro-mental do requerente;

$\S 2^{\circ}$ - Os portadores de qualquer doença mental ou nervosa, congênita ou adquirida, não sendo casados com brasileiros natos ou não tendo filhos nascidos no Brasil, poderão ser repatriados, mediante acôrdo com os govêrnos dos respectivos países de origem. (dec.24.559, art.25 - Brasil, 3 jul. 1934)

Eis o eugenismo legislativo brasileiro em sua essência: uma confusa mistura de eugenia com xenofobia, a reduzir a purificação racial à repatriação de estrangeiros.

Após o decreto 24.559, um único ato legislativo conclui o período que vai da constituição da República brasileira à Segunda Guerra Mundial. Ainda no espírito de ampliação estatal, o decreto-lei 3.138, de 24 de março de 1941, “dispõe sobre a assistência médica, pelos Institutos e Caixas de Aposentadoria e Pensões, dos doentes mentais que forem seus segurados ou associados". Por ele, o nascente sistema previdenciário brasileiro formaliza seu interesse pelo tratamento dos transtornos mentais, o prenúncio de um novo gênero de relações entre Estado e saúde mental, como veremos a seguir.

\section{O desenvolvimentismo brasileiro}

Nos dois primeiros itens deste trabalho, abordo as características do pensamento legislativo brasileiro concernente à saúde mental, na primeira metade do século XX. Passo agora a analisar o perfil que o tema assume a partir das mudanças provocadas na ordem política e social, ao final da Segunda Guerra Mundial. O período compreendido neste item inicia-se, portanto, em 1946 e estende-se até 1982, quando uma portaria do Ministério da Previdência e Assistência Social inaugurou uma nova era nas relações entre a assistência à saúde mental e o Estado.

Do ponto de vista metodológico, as peculiaridades do período sob exame exigiram uma ligeira mudança de exposição em relação aos itens anteriores. Por haver simultaneamente, no corpo legislativo, duas interpretações acerca do papel da saúde (geral e mental) na sociedade, não cumpro aqui a ordem cronológica em que as leis foram promulgadas. A análise realiza-se com base nas duas interpretações, havendo, na realidade, duas cronologias simultâneas, correspondendo a dois espíritos diferentes, consistindo num aparente paradoxo.

A característica conflituosa desse período é assim exposta por Resende (2000, p.17):

a história das políticas de assistência ao doente mental no Brasil é, antes de tudo, um crônica de desencontros, propostas e práticas concretas nem sempre caminhando lado a lado... Este divórcio entre discursos e ações torna-se tanto mais evidente quanto mais próximo do período recente, devido à emergência de múltiplos - e freqüentemente contraditórios entre si - interesses dos diversos grupos no poder. Torna-se, por isso, difícil 
ao pesquisador pinçar este ou aquele discurso como hegemônico sem correr o risco de incorrer em alto grau de arbitrariedade.

Luz (1986) encontra a mesma ausência de hegemonia ao analisar as instituições médicas do Brasil do pós-guerra. A despeito das dificuldades que a investigação dessa época encerra, penso ser possível acrescentar alguma colaboração, ainda que a título introdutório.

Alguns atos têm o poder de conter em si a síntese de um período histórico e, quando cotejados com outros de mesma índole, ampliam, por contraste, as diferenças entre determinadas épocas. Os mencionados decretos de 1923, que declaravam de utilidade pública a Liga Nacional contra o Alcoolismo e a Liga Brasileira de Hygiene Mental, exemplificam o espírito higienista que informava a compreensão dos fenômenos mentais na primeira metade do século XX. Do período ora em exame, parece emblemático o decreto 28.096, de 10 de maio de 1950, que "declara de utilidade pública o Instituto Brasileiro de Psicanálise, com sede nesta Capital". 'Do higienismo à psicanálise' poderia ser o mote dessa fase, em que ressalta uma descontinuidade em relação aos dois períodos anteriores, com a assunção de outro paradigma para a interpretação da saúde mental e, conseqüentemente, para a lapidação de leis que the serviram de apoio.

O ponto de ruptura é o final da Segunda Guerra Mundial. Com a vitória das nações democráticas e com o choque perante a barbárie sem precedentes, vivida durante seis anos, a humanidade reassumiu sua vocação para construir a civilização a partir de valores humanistas. O regime varguista ditatorial, apenas tardiamente aliado às forças democráticas, perdeu sua razão de ser e o Brasil viveu um período de abertura política e otimismo institucional. Nessa espécie de bonança posterior à tempestade nazi-fascista, a psicanálise tomou a frente e tornouse a vertente de conhecimentos ligados à saúde mental que mais teve a oferecer naqueles novos tempos.

Não é meu objetivo acompanhar a evolução da noção de psicopatologia na psicanálise. Contudo, a título de ilustração dos contrastes entre os períodos anteriores e este de que agora trato, examino agora como o conceito de higiene foi utilizado pela saúde mental de inspiração psicanalítica. Para a tarefa recorro a Mário Yahn - psiquiatra dos centros de saúde da cidade de São Paulo - e sua obra Higiene mental e saúde pública, publicada em 1955. A escolha desse autor para representar o período justifica-se por sua relevância tanto na psiquiatria quanto na psicanálise brasileiras da metade do século XX, além do interesse na construção de intervenções sobre o corpo social. ${ }^{10}$

Veremos que, em princípio, a permanência do conceito de higiene pode nos levar a concluir pela continuidade do higienismo dos anos 20 a 40, mas a ruptura fica evidente quando se observa o enorme deslizamento de seu uso e significado.

\section{A psicopatologia em Mario Yahn}

A abstração da profilaxia

A psicopatologia naturalista da primeira metade do século XX considerava a hereditariedade o fator principal da degeneração. Secundariamente, apoiava-se em uma teoria naturalista do meio físico como causa das doenças mentais. Nas duas formulações, o trajeto que levava à 
alienação ou à psicopatia consistia em uma cadeia de causas concretas e físicas. Sua profilaxia, por extensão, era uma profilaxia física.

O período psicanalítico inverte essa equação, afastando a profilaxia da concretude física e amarrando-a à cultura. Na nova composição, a profilaxia aproxima-se da educação: "Ao educar, estamos contribuindo para integrar o homem no nível cultural atingido pelo seu meio e, dessa forma, muitas vêzes, sem o saber, realizamos a profilaxia de desajustamentos futuros"(Yahn, 1955, p.11). A profilaxia se dá na medida da cultura. Quando o homem, pela via da educação, alça-se a um nível de cultura que lhe é próprio dá-se a profilaxia, voluntária ou involuntariamente. A proteção psíquica é diretamente proporcional à inserção cultural. Esta é a chave do pensamento do higienista; não mais o assistencialismo religioso ou a ordem pública da República primeira, mas a inserção cultural como norma a ser perseguida. Daí decorre que os instrumentos para a higiene mental sejam identificados com os instrumentos para o acesso cultural, e essa mudança de estratégias redefine o perfil dos profissionais envolvidos com a saúde mental. Portanto, é da assunção da profilaxia como abstração que derivam as próximas características.

\section{A promoção da psicologia e a confluência profissional}

As novas relações entre psicólogo e médico são enunciadas, na obra de Yahn (1955), já no início da Introdução: "No nosso livro Higiene Mental, publicado em 1952, procuramos trazer para o trabalho clínico nos Centros de Saúde, a contribuição do psicólogo para que as preocupações do médico pudessem ir além da rotina habitual, ampliando-se para os setores psicológico e social dos clientes e suas famílias" (p.11). A agenda cultural-profilática alarga a interface entre médico e psicólogo, exige do primeiro um olhar que ultrapasse a doença e adentre o território psicossocial do doente. Do segundo, evoca suas imbricações com a pedagogia: "Pudemos, sobretudo, apreciar a transição suave que existe da educação para a psicoterapia" (p.11).

Já a aproximação entre psicoterapia e educação sanitária é radical. Yahn $(1955$, p.23) afirmava haver

uma transição imperceptível entre a educação e a psicoterapia. Não sabemos bem quando termina uma e começa outra. Há formas graves de desvios psicológicos que exigem técnicas especiais de psicoterapia, dentre as quais as mais completas e profundas são as psicanalíticas. Em casos comuns, porém, a necessária influência educativa, exercida em bases racionais, inclui a assistência psicológica e se confunde com a psicoterapia.

Diluem-se as especificidades profissionais, mesclam-se as atividades médicas, pedagógicas e psicológicas - com crescente ênfase para esta última. Suas fronteiras não são distinguíveis com clareza, mas essas áreas têm uma raiz comum indeclinável, a psicanálise. Serão todas braços expressivos de uma agenda comandada pela percepção psicanalítica:

Assinalando uma nova era, que seria a terceira fase da assistência à Saúde Pública, destacase o particular desenvolvimento alcançado pela psicologia, que data, aproximadamente, de 60 anos, com o descobrimento da psicanálise. (Yahn, 1955, p.19)

Deve-se à psicanálise, à antropologia e à sociologia a contribuição básica para as novas aplicações práticas da psicologia, reunidas sob a denominação de psicologia das interrelações humanas. (p.27) 
O trecho seguinte elucida de vez as novas inspirações do pensamento higienista em saúde mental pública. As grandes ciências da cultura são a base intelectual de uma agenda que tem na cultura o grande objetivo da profilaxia e na psicologia clínica, sua ação mais eficaz: "Vemos, pois, que o Centro de Saúde, através de suas atividades profiláticas e educativas, pode e deve realizar um trabalho de psicologia clínica, que é um dos aspectos da Higiene Mental, talvez o mais importante". (Yahn, 1955, p.26)

\title{
A psicopatologia como desajustamento
}

Em conseqüência do destaque da cultura na visão do psicopatologista de influência psicanalítica, a noção de psicopatologia recebe uma nova acepção. Antes balizada na neuropatologia, começa a orientar-se por sua relação com a cultura. No período inicial, a saúde mental mirava a ordem; agora almeja o ajustamento: "quanto mais perfeito nosso ajustamento ao meio familiar e social, melhor será nossa saúde física e mental. A educação, no seu real sentido, conduz o indivíduo a êsse ajustamento" (Yahn, 1955, p.12).

Em benefício de uma melhor compreensão das idéias do autor, precisemos o que ele denomina 'ajustamento' familiar e social:

\begin{abstract}
Assim, não podemos visar o indivíduo isolado, ainda que o consideremos sob o ponto de vista físico, psíquico e social. Torna-se necessário trabalhar num plano muito mais elevado e geral, vendo, sempre, em pleno foco das nossas cogitações, a família, em conexão permanente e indissolúvel com os problemas da maternidade, infância e adolescência...

A família é o centro de gravidade de todos os problemas, dentre os quais o da psicologia das relações interpessoais ou inter-humanas. (Yahn, 1955, p.25-26).
\end{abstract}

Aquilo que a princípio parecia equiparar meio familiar e social, quando investigado com mais profundidade revela a família como objeto fulcral da higiene mental. Observe-se agora o conceito de desajustamento no meio familiar: "Mães e filhos são apreciados através dos conflitos que, entre ambos, sempre existem. Tais conflitos, se não evitados a tempo, criam o nervosismo e as neuroses infantis que são o núcleo e a base de neuroses e psicoses encontradas na idade adulta" (Yahn, 1955, p.24). A idéia de conflito como gênese da patologia e sobretudo a orientação de evitá-lo, como melhor estratégia profilática, sustenta o pensamento do autor: "é possível viver melhor, inclusive no plano da saúde física, quando nós nos entendermos melhor e evitarmos os conflitos internos" (p.21).

Em suma, a psicopatologia, tratada por grandes categorias como psicose e neurose, surge como desajustamento das relações interpessoais familiares, o qual, por sua vez, deve ser enfrentado para evitar conflitos interpessoais ou intrapessoais. O pressuposto dessa rede de raciocínios é que pode haver um mundo sem conflitos, a ser atingido com uma atitude pedagógica e racional:

Em contato com o educando, devemos não só observá-lo, mas ouvir com interesse a sua história e as suas queixas para ver surgir, como uma imanência, possíveis conflitos na sua vida de família e, conseqüentemente, podermos dar o conselho oportuno, indicar a orientação certa, recomendar a atitude conveniente, auxiliando-o a resolver problemas psicológicos que entravam a normalidade de sua vida. (Yahn, 1955, p.12) 
Note-se que, para o autor, a psicopatologia deve ser abordada com uma nota de paternalismo, uma face apaziguadora superficial, como veremos adiante.

\section{O deslocamento do eixo institucional de atuação}

O grande hospício da primeira metade do século jamais serviria aos propósitos dessa agenda cultural-psicanalítica. Um pensamento que procura disseminar sua atuação pelos interstícios familiares não pode ser implementado entre as paredes de um complexo institucional. A profilaxia mental desloca-se, então, dos projetos hospitalares para o centro de saúde, onde a ampla gama de interesses higienistas pode vir à luz de modo mais efetivo:

O Centro de Saúde pode representar, sob várias formas, êsse centro de interêsse tão importante, através da assistência médico-sanitária que, sistematicamente proporciona aos que o procuram.

Mas o Centro de Saúde não se limita a essa assistência médica. Vai além. Tendo finalidade educativa, desenvolve múltiplas atividades, proporcionando meios para a implantação de hábitos sadios e para a orientação psicológica para cada caso, e social - no plano existencial. Assim, o paciente encontra no Centro de Saúde muito mais do que imagina ou deseja obter "(Yahn, 1955, p.28).

O amplo e ambicioso projeto humanista do psiquiatra do pós-guerra tinha para o Centro de Saúde planos bastante relevantes, muito mais do que a mera assistência médica psiquiátrica.

\section{O aparente paradoxo brasileiro}

A interpretação que acabamos de realizar, se não representa a totalidade do pensamento em saúde mental do período do pós-guerra, no Brasil, seguramente expõe uma certa concepção de mundo que vigorou então e que pode ajudar na compreensão do aparente paradoxo mencionado anteriormente. Devemos, agora, lançar os termos do paradoxo. Este toma forma à medida que percorremos a cadeia de atos legislativos relacionados à saúde em geral que foram introduzidos no Brasil nas quatro décadas posteriores a 1945. Ponderemos acerca de suas particularidades.

A redução da autonomia legislativa da saúde mental

Não há, no período, nenhuma norma jurídica específica de saúde mental, quer em termos de assistência ou proteção aos indivíduos portadores de enfermidades mentais. Ela é regulada por meio de leis e decretos gerais sobre saúde. Compartilhando espaço com a atenção global à saúde, perde em autonomia e especificidade no plano jurídico. Esse adelgaçamento pode ser compreendido sob dois aspectos. Em primeiro lugar, como a face legislativa da interpretação culturalista de psicopatologia. O movimento que vê na saúde mental um dos pilares da inserção cultural deságua, quase necessariamente, na redução de sua importância relativa e de seu perímetro de particularidades. (No limite, ele também termina por reduzir a psicologia a um posto avançado da pedagogia.) A menor importância relativa da saúde mental concretiza-se, enfim, pelo menor peso relativo de suas normas. O segundo aspecto, de natureza conjuntural, refere-se ao enfraquecimento do Estado totalitário varguista e de seus tentáculos de ordenação social. 
Embora com uma menor autonomia jurídica, a progressão da saúde mental não foi paralisada, no que tange à busca por melhores modelos para a sua construção e manutenção na sociedade, como atesta a grande peça legislativa sanitária do período, o decreto 49.974 , de 21 de janeiro de 1961, que regulamentou o Código Nacional de Saúde, cujas normas deveriam ser observadas em todo o país, "por qualquer pessoa, física ou jurídica, de direito público ou privado..." (art.1).

O Código Nacional de Saúde de 1961 e as novas preocupações do modelo assistencial e da proteção individual

Nessa peça jurídica de ampla abrangência encontra-se a principal normatização da área mental, do período em estudo. Refiro-me ao capítulo 2 (Saúde Mental - Psico-higiene e Assistência Psiquiátrica) do título 2 (Promoção da Saúde) do Código (dec.49.974 - Brasil, 21 jan. 1961). A seguir, indico o que considero suas principais características.

\section{A preocupação com a redução das internações psiquiátricas.}

O primeiro artigo do capítulo sobre saúde mental declarava os princípios da política sanitária: "A política sanitária nacional, com referência à saúde mental, é orientada pelo Ministério da Saúde, no sentido da prevenção da doença e da redução, ao mínimo possível, dos internamentos em estabelecimentos nosocomiais" (dec.49.974, art.75 - Brasil, 21 jan. 1961). O legislador do pós-guerra, intérprete psicanalítico e cultural dos problemas mentais, não via no nosocômio o melhor instrumento para a execução de suas políticas. Ainda que consciente da inevitabilidade da internação como recurso terapêutico, recomendava que ela se restringisse ao mínimo necessário. Era no meio cultural que se devia responder a problemas nele originados, e não mais no hospício, que teve sua posição enfraquecida na rede terapêutica.

\section{O modelo assistencial}

Os novos tempos procuravam novos modelos que servissem a seus propósitos e suas concepções de mundo. Para configurar o modelo assistencial de tal agenda culturalista, cabia ao Ministério da Saúde fomentar "a criação de 'centros de elucidação de diagnóstico' como organizações para-hospitalares, de 'hospitais de dia' e de serviços 'assistência aberta', públicos ou privados, aos quais poderá dar cooperação técnica e material" (dec.49.974-A, art.77, par.1 - Brasil, 21 jan. 1961). Todo o aparato institucional atento para a permanência do doente mental o mais próximo possível de sua cultura encontrava-se aí formalizado. Mas a ambição do projeto fez a legislação ir mais adiante, estendendo o equipamento extra-hospitalar à família do doente e contemplando também o dependente químico: "As instituições de amparo social à família do psicopata indigente e os centros de recuperação profissional para alcoolistas e outros toxicômanos, exercerão suas atividades de psico-higiene, através de organizações parahospitalares" (art.84).

A expressão mais acabada das estratégias políticas do período encontra-se no artigo 85: "O Ministério da Saúde organizará e estimulará a criação de serviços psiquiátrico-sociais de assistência tanto aos pacientes egressos de nosocômios, como as famílias, no próprio meio social ou familiar" (dec.49.974-A - Brasil, 21 jan. 1961). A intenção é clara: a assistência seria oferecida 
sobretudo em meio à sociedade e à família, ou seja, nos locais em que a vida cultural se exerce e onde se molda o desenvolvimento psicológico individual. Não sendo possível, a assistência deveria ser oferecida em hospitais, respeitando-se, no entanto, o princípio de redução de autonomia do aparato da saúde mental: "O Ministério da Saúde tomará providências para a criação de "anexos psiquiátricos" nos hospitais gerais..." (art.86).

Observa-se um patente otimismo quanto às potencialidades da saúde mental - via higiene mental - na forja do desenvolvimento sociocultural, que alcançava por vezes tons ufanistas, talvez próprios da época, a exemplo dessas palavras de Yahn (1955, p.29):

Há outros setores em que se pode desenvolver com êxito um trabalho de Higiene Mental. Assim, nos centros industriais, onde os interêsses de empregados e empregadores se defrontam, o psicólogo pode estudar as causas emocionais dos conflitos, indicando a orientação psicológica mais adequada. A escola, quer primária, quer secundária ou superior, sendo centro de interêsse onde as aspirações de professores, pais e alunos convergem, oferecem um campo de pesquisa e orientação psicológica de primeira ordem, com o que haverá a harmonia dos grupos tão necessária ao bem-estar de cada indivíduo e da sociedade.

Os artigos em exame do Código Nacional de Saúde parecem ser a expressão legislativa desse projeto de terapêutica psicológica da sociedade.

\section{O alargamento da assistência}

Sob tal espírito de investimento psicológico na sociedade, pode-se entender o aumento da população passível de receber atenção psiquiátrica. A população carcerária custodiada pelo Estado foi incluída na assistência psiquiátrica, mantendo-se para ela os princípios gerais da assistência à população geral, com especial ênfase na prevenção:

Os 'anexos psiquiátricos' das Casas de Detenção e Penitenciárias, terão por objetivo a assistência e o tratamento, sob guarda, dos reclusos que denotarem reações psicopáticas tendo por atribuição o estudo sistemático e compulsório da personalidade dêstes, para seleção dos casos passíveis de assistência e tratamento, no sentido da psiquiatria preventiva. (dec.49.974-A, art.87 - Brasil, 21 jan. 1961)

\section{A epidemiologia como princípio}

Pela primeira vez na legislação de saúde mental, surgiu o termo epidemiologia, não como mera referência secundária, mas como princípio: "O Ministério da Saúde promoverá investigações epidemiológicas, sôbre a prevalência e a incidência das doenças mentais no país" (dec.49.974, art.83 - Brasil, 21 jan. 1961). A lei considerava relevante a estratégia epidemiológica, para a condução de uma política pública. Com isso, abandonavam-se em definitivo as preocupações com a ordem pública, manifestas nas leis dos períodos anteriores e que acabavam por ressaltar as doenças mais comprometedoras dessa ordem, os transtornos mais graves. A partir do princípio epidemiológico, o foco transferiu-se para as necessidades reais da totalidade da população, independentemente de suas conseqüências comportamentais. Tais intenções ainda aguardam, em nossos dias, ações à altura, mas não deixa de ser um marco o momento em que o olhar epidemiológico foi introduzido na legislação brasileira sobre saúde mental, quando a doença passou ser vista como tal e não por suas derivações. 
A proteção cultural

Analisei anteriormente, na confluência das profissões relacionadas à saúde mental, o imbricamento da psiquiatria com a psicologia; a aproximação de ambas a ciências da sociedade e da cultura como a sociologia e a pedagogia; e como todo esse movimento foi capitaneado por uma agenda mais ampla, de abrangência cultural, otimista quanto às suas possibilidades. Mas o humanismo do pós-guerra não ocultou seus adversários, como parecem atestar os seguintes artigos do Código Nacional de Saúde de 1961.

Art.80: É vedada, quer nos estabelecimentos destinados à assistência a psicopatas, quer fora dêles, a pratica de quaisquer atos litúrgicos de religião, culto ou seita, com finalidade terapêutica, ainda que a título filantrópico e exercida gratuitamente.

Art.81: É vedada a pessoas sem habilitação legal para o exercício da profissão, a prática de técnicas psicológicas com fundamento nos processos de sugestão capazes de infundar o estado mental de indivíduos ou de coletividades, ainda que sem finalidades de proteção ou de recuperação da saúde.

Art.82: Qualquer autoridade pública local tem o dever de notificar, imediatamente, às autoridades sanitárias competentes, a eclosão de 'epidemia de crendice terapêutica' de qualquer natureza, com aspectos de contágio psíquico, propiciando psicoses induzidas, fanatismo de multidões ou loucura coletiva. (dec.49.974-A - Brasil, 21 jan. 1961)

A antiga rixa com a religião retornava, já não mais como conflito pela liderança assistencial pois a hegemonia laica tornara-se definitiva e não se tratava de uma questão institucional -, mas como especificidade terapêutica. A lei procurava impedir o uso terapêutico da religião. A terapêutica conduzida por médicos e psicólogos, conforme os princípios das respectivas ciências, devia ter primazia na ação sobre a sociedade. Mais ainda: a terapêutica devia ser protegida contra pessoas não-qualificadas profissionalmente, que atuavam com técnicas não-reconhecidas ("crendices terapêuticas"). Ela era um braço importante da concepção cultural-humanista da saúde mental e devia, portanto, manter-se imune a intervenções sobre o psiquismo da população. Um projeto de saúde mental cujos objetivos maiores eram o esclarecimento familiar e social e a solução racional-pedagógica de conflitos elegia como seu maior antagonista quem se opunha a essa consciência esclarecida. Atos litúrgicos, sugestionamentos e crendices, antípodas desses princípios culturais, ações entorpecedoras de uma clara consciência humanista, seriam os adversários a banir.

\section{A proteção individual}

Por fim - e por inferência do que acabamos de ver -, reproduzia-se a intenção de proteger os direitos individuais do paciente, ainda que com menor relevância em relação às primeiras normas, em que se procurava estabelecer pela primeira vez, em outra atmosfera cultural, alguma proteção individual. Firmava-se no artigo 77 do Código a proteção contra abusos: "Sòmente poderá ser efetivada a internação em estabelecimento nosocomial destinado ao tratamento de doenças mentais, e como tal registrado, o doente que após a indispensável observação e elucidação do diagnóstico, fôr reconhecido como doente mental". 
A expansão da rede hospitalar e a participação privada

Com o Código Nacional de Saúde, essa grande regulamentação da saúde mental do pósguerra, seus cuidados com a redução de internações psiquiátricas e sua atenção ao tema da localização social e familiar da assistência, esperam-se desdobramentos como atitudes administrativas de multiplicação de centros de saúde, equipamentos para-hospitalares ou anexos psiquiátricos em hospitais gerais. No entanto é o inverso que ocorre, e delineia-se um cenário que parece constituir um paradoxo.

Em 1946, por meio do decreto-lei 8.550 (Brasil, 3 jan. 1946), autorizava-se o Ministério da Educação e Saúde a "celebrar Acôrdos, visando a intensificação da assistência psiquiátrica no território nacional". O decreto procurava otimizar a assistência psiquiátrica "nas regiões em que os estudos... revelarem deficiências" (art.1), revelando uma intenção epidemiológica. O projeto de ampliação assistencial tem ainda no poder público seus principais motores estratégicos, financeiros e administrativos, reunindo forças da federação e dos estados:

\footnotetext{
Os Acordos disciplinarão a matéria relativa à construção, instalação e funcionamento de hospitais e serviços psiquiátricos nos Estados..., atendidas as bases seguintes:

I - Caberá ao Estado, quando fôr o caso, dar terreno para as edificações;

II - Os projetos de construção serão aprovados pela União;

III - As despesas de construção e instalação serão custeadas pela União e pelo estado, na proporção que fôr fixada;

IV - As despesas de funcionamento ficarão sob a exclusiva responsabilidade do Estado..." (dec.-lei 8.550, art.2 - Brasil, 3 jan. 1946)
}

O Estado brasileiro do imediato pós-guerra, capitalizado, fornecia as condições materiais para um projeto de expansão psiquiátrica que abrangeria, no ano seguinte, a oferta de benefícios fiscais aos empreendedores privados. O decreto 22.561, de 7 de fevereiro de 1947, concedia "favores fiscais aos Estabelecimentos Hospitalares que se construírem no Distrito Federal...". O artigo 3, ainda que não tratasse estritamente da saúde mental, indica o paradoxo do período sob análise e mostra a atmosfera cultural que motivava essa expansão hospitalar: "Para que possam gozar das vantagens previstas neste Decreto, os estabelecimentos hospitalares a serem construídos deverão dispor no mínimo de duzentos leitos" (dec.22.561 - Brasil, 7 fev. 1947). Há uma contradição entre uma agenda que postula assistir a saúde mental e tratá-la no próprio meio social e familiar e a exigência mínima de duzentos leitos hospitalares, para a aprovação da renúncia fiscal. Há igualmente o paradoxo da coexistência de uma política hospitalar grandiosa em termos físicos com uma política de saúde ambiciosa em termos humanos, mas oposta ao isolamento físico.

A mais nítida expressão desse paradoxo revela-se na comparação entre o Plano Salte, aprovado em 1950 (ano em que foi declarado de utilidade pública o Instituto Brasileiro de Psicanálise) para orientar o desenvolvimento socioeconômico do país, e os artigos do título referente à saúde mental do Código Nacional da Saúde. O Plano Salte, que abrangia os setores de saúde, alimentação, transporte e energia, apresentava o planejamento orçamentário de 1950 a 1954. Em assistência psiquiátrica, tinha por meta a "construção de 10.000 leitos, na base de Cr\$20.000,00 por leito, a fim de atingir a taxa de 1 leito por 1.000 habitantes" (lei 1.102, item j - Brasil, 18 maio 1950). Independentemente da discussão sobre a meta - cerca de 
quatro vezes a atual proporção leito/habitantes no Brasil -, chama a atenção a franca dissonância conceitual com o Código, que prescreveria, poucos anos depois, uma assistência para-hospitalar ou aberta, dissonância que pode ser interpretada como um conflito surdo entre duas concepções, separadas pela Segunda Guerra Mundial.

É fato que a psiquiatria ainda não dispunha, na ocasião, do aparato farmacológico de que dispõe hoje para facilitar o tratamento não-hospitalar. Entretanto, do que foi analisado fica saliente que a opção pela terapêutica extra-hospitalar dependeu mais de preceitos diferentes acerca da psicopatologia do que propriamente da disponibilidade de arsenal terapêutico.

Se houve divergências entre o setor de saúde mental e os planejadores estatais, o exame do ocorrido ao cabo de algumas décadas indica claramente o vencedor. Em 1941, ainda em meio à Segunda Guerra Mundial, havia 65 hospitais psiquiátricos no país, dos quais 31 pertenciam à esfera pública e 34, à privada. Em 1961, portanto após o Plano Salte, existiam 140 hospitais, sendo 86 privados e 54 públicos. Dez anos depois, no segundo lustro do governo militar, quando se deu a mais ampla privatização de serviços de saúde da história do país (Luz, 1986; Paulin, Turato, maio-ago. 2004), 340 hospitais distribuíam-se pelo território nacional, sendo 277 privados e 63 públicos. Em 1981 a rede hospitalar cresceu ainda mais, alcançando 425 hospitais, 362 privados e 63 públicos. Nenhum hospital público foi aberto entre 1971 e 1981. Em quarenta anos, o número de hospitais psiquiátricos sextuplicou. A rede privada ampliouse quase 11 vezes, ao passo que a pública cresceu duas vezes (Figueiredo, jan.-dez. 2001).

Na prática, todos os governos do período mantiveram o mesmo projeto psiquiátrico. A despeito de suas enormes e irreconciliáveis diferenças, que tanto desestabilizaram a cena política do país, os gestores do Estado brasileiro ofereceram uma única opção para a saúde brasileira: a expansão física de um modelo ultrapassado, cuja novidade única consistia na privatização, facilitada enormemente por recursos governamentais. Confundiu-se desenvolvimentismo econômico - a criação e estabelecimento do parque industrial - com desenvolvimento da saúde, e esta foi reduzida a um braço estratégico menor da economia. Nesse ponto da nossa história, no que concerne à assistência à saúde mental, criou-se um abismo entre o Brasil e o mundo, que ainda em nossos dias não conseguimos superar. A experiência internacional do pós-guerra tendeu a rejeitar os grandes hospitais de início do século, substituindo-os por uma diversidade de experiências que, menos ou mais bem-sucedidas, conduziram a assistência em saúde mental a rumos que isolaram o Brasil.

Uma análise mais detida do período ajuda a compreender uma lógica subjacente ao paradoxo apontado, reduzindo o conflito entre as duas tendências aparentemente irreconciliáveis. Mota (1994), ao investigar o pensamento brasileiro dos anos do desenvolvimentismo, pondera: "A aliança entre as classes torna-se o pressuposto básico, em termos de organização social, nessa fabricação ideológica da burguesia desenvolvimentista, reformista, nacionalista. Burguesia para a qual a questão cultural se resume na transformação do aparelho pedagógico, na criação de escolas técnicas e profissionais..." (p.173). Ora, não seria o pensamento de Mário Yahn a expressão mais acabada dessa formação ideológica, que acreditava bastar à nação o diálogo, a supressão de conflitos e a compreensão paternalista para que o bem comum fosse atingido? A psicopatologia em Yahn é a versão sanitária da aliança entre as classes, agora transposta para a aliança entre pais e filhos, entre família e cultura. 
Assim, embora sua interpretação de saúde e patologia fosse genuinamente diversa daquelas existentes em épocas anteriores, o humanismo desenvolvimentista do pós-guerra parece ter sido conivente com a subordinação da saúde (e não somente a mental) a um projeto nacionalista indiferente às reais necessidades sanitárias da população.

\section{Conclusão}

O exame das leis e normas promulgadas na República brasileira relativas ao padecimento mental pode ser melhor compreendido se o dividirmos em três períodos distintos. O período inicial (1890-1910), que, do ponto de vista legislativo, abrange da primeira norma republicana, o decreto 142, de 1890, ao decreto 1.132, de 1903, caracteriza-se pela introdução do tema da patologia mental nas atribuições do Estado, com três peculiaridades principais.

A primeira delas, e mais relevante devido a seu caráter universal, é o reconhecimento e a preservação dos direitos dos portadores dessas patologias. Seja no seu aspecto de proteção aos direitos individuais (sobretudo quanto a seqüestros arbitrários e proteção de bens), ou de regulamentação e vigilância da qualidade dos serviços fornecidos, o intuito fundamental do legislador brasileiro, nesse período, foi salvaguardar aquilo que, na época contemporânea, denominaríamos direitos de cidadania. A segunda peculiaridade refere-se à passagem da jurisdição religiosa para o campo laico; uma das motivações das primeiras normas republicanas foi a de retirar da alçada religiosa as instituições para doentes mentais e passá-las para a esfera laica. A terceira concerne à maneira com que a legislação em saúde mental foi influenciada pela cultura da época. Para além do núcleo dessas normas (os direitos individuais), os reflexos do país recém-saído da escravidão são visíveis. Preocupações extremadas com a manutenção da ordem pública, rigidez hierárquica e tratamento diferenciado para os de condição social inferior destacam-se entre essas manifestações. Complementa esse quadro uma interpretação estritamente neuropatológica dos fenômenos psicopatológicos, informada pelas noções de hereditariedade e degeneração.

No período de ampliação da ação estatal (1911-1945), a investigação dos atos normativos promulgados entre 1911 e 1934 permite concluir uma continuidade em relação ao período anterior, expressa na manutenção do interesse, por parte do Estado, pela proteção dos indivíduos acometidos por problemas mentais. Igualmente a interpretação sobre adoecimento mental não sofre alterações substanciais, a despeito do alargamento de sua abrangência. Mas tais semelhanças não se sobrepõem a diferenças relevantes, que justificam a demarcação dos dois períodos.

O ponto distintivo do segundo período foi a crescente ampliação do poder estatal sobre a saúde da população, que incluía a possibilidade de intervenção policial. O Estado passou a ter o direito de intervir sobre a sociedade para formatar suas ações sanitárias. O tema da higiene e profilaxia cresce em importância. Em tal contexto, duas particularidades destacam-se na saúde mental: a ampliação das ações sanitárias até áreas não contempladas anteriormente, com destaque para a toxicomania; e o esboço de um eugenismo legislativo, restrito a medidas ligadas ao repatriamento de estrangeiros portadores de doenças mentais.

Por fim, o período do desenvolvimentismo brasileiro (1946-1982) é marcado por uma patente descontinuidade com relação aos anteriores, em grande parte devido à crescente 
complexidade do setor da saúde mental. Se nos dois primeiros períodos foi possível detectar uma corrente única de pensamento, no pós-guerra várias influências político-culturais se fizeram notar, inviabilizando uma abordagem unívoca sobre o fenômeno. Do ponto de vista administrativo e institucional, prevaleceu o espírito desenvolvimentista que, apesar de um ligeiro deslizamento de propósitos ao longo dos anos, tinha uma visão estritamente econômica de desenvolvimento social. Tanto nos governos democráticos dos anos 40 e 50 quanto no regime militar, nas duas décadas seguintes, prevaleceu a noção de que o investimento na economia (inicialmente na indústria, em seguida em infra-estrutura), bastaria para tornar o país justo e apto a participar do primeiro time do mundo ocidental.

A saúde mental jamais foi estrela de primeira grandeza dessa agenda, sendo entendida como fator secundário a agregar valor ao progresso. A lógica que moveu as políticas do período foi a do empreendedorismo industrial, e o balanço das ações promovidas em saúde mental confirma esta tese. O parque hospitalar brasileiro privado cresceu à semelhança do parque industrial e infra-estrutural. Ambos eram avaliados pelo número de plantas e, sobretudo, pela crescente participação privada, apoiada pelo poder público.

A expansão hospitalar, desinteressada por qualquer rumo que não o econômico, manteve o padrão anterior de interpretação acerca da psicopatologia. Neste sentido, há que ressaltar que os manicômios iniciais ainda tinham, a seu favor, uma ambição intelectual, uma visão de mundo pela qual se orientar. Para o bem ou para o mal, tiveram um projeto sanitário para a sociedade, ao contrário da expansão hospitalar do pós-guerra, como o demonstra a análise do corpo de leis que a conduziu. A primazia do pensamento econômico-industrial, contudo, conviveu com o florescimento de uma percepção acentuadamente humanista da psicopatologia. A emergência da psicanálise como frontispício intelectual de toda uma visão de mundo e da cultura, iniciou a transformação da velha Weltanschauung das doenças neuropatológicas e seu necessário manicômio. Os princípios expressos no Código Nacional de Saúde mostram que, embora minoritária em sua expressão política, sua contribuição para a construção de uma nova visão de saúde mental foi irrevogável. No entanto pode-se postular que essa noção psicanalítica de saúde pública do início do pós-guerra tenha atuado de modo conservador, favorecendo a consolidação da ideologia do desenvolvimentismo. Ao identificar ajustamento familiar e social com saúde mental, e tendo como objetivo evitar conflitos, essa psicanálise pública primeva teria sido a expressão sanitária de um anseio de pacificação dos conflitos sociais, fundamental para a agenda econômica e de manutenção do status quo, deixando intocadas questões que somente viriam à tona anos depois, com a Reforma Psiquiátrica.

\section{AGRADECIMENTOS}

À Fundação Djalma Guimarães, responsável pelo financiamento do projeto que resultou neste trabalho. Ao professor Valentim Gentil Filho, pela oferta das condições para o desenvolvimento deste trabalho. À senhora Iolanda Feitosa, pelo auxílio no levantamento dos textos das leis. 


\section{NOTAS}

${ }^{1}$ Todas as leis e regulamentos estudados neste artigo estão disponíveis no sítio eletrônico Sistema de Informações do Congresso Nacional (http://www6.senado.gov.br/sicon).

${ }^{2}$ A expressão 'saúde mental' não é mencionada em nenhum documento desse período, por ser uma construção conceitual do pós-Segunda Guerra Mundial (Bertolote, 2000). Ressalte-se, portanto, que as interpretações acerca das alterações mentais e as condutas a serem tomadas em relação a elas eram distintas daquelas vinculadas ao que contemporaneamente denomina-se o campo da saúde mental. Poder-se-ia empregar, para os anos anteriores à Segunda Guerra Mundial, a noção higiene mental, de uso corrente então, mas ela me parece igualmente inadequada nesta pesquisa, uma vez que as leis e os regulamentos em análise apresentam uma relação bastante frágil e mutável com as estratégias especificas de higiene mental.

${ }^{3}$ Nesta e em todas as citações a seguir mantenho a grafia original dos diversos decretos, normas e leis.

${ }^{4}$ Este e todos os grifos, nas citações, são de minha autoria.

${ }^{5}$ Da mesma maneira, a tese foucaultina que relaciona o surgimento da psiquiatria ao desenvolvimento de estratégias de controle social vem sendo contestada por recentes interpretações históricas (Porter, 1992; Freitas, jan.-abr. 2004).

${ }^{6}$ Considero como noção moderna de psicopatologia aquela proposta por Karl Jaspers em Psicopatologia geral, publicado em 1913. O critério que nos guia para essa assunção é o postulado de uma psicopatologia como ciência autônoma e independente, legado principal do autor.

${ }^{7}$ Emil Kraepelin (1856-1926) é por muitos considerado o pai da psiquiatria moderna. Sua sistematização das doenças mentais é ainda nos dias de hoje tomada como ponto de referência intelectual.

${ }^{8}$ A esse respeito, ver Stepan, 2005, e Souza, 2006.

${ }^{9}$ A despeito da grande relevância dessa obra, a nos apresentar a eugenia no Brasil em análise detalhada, discordamos do autor quanto à afirmação de terem sido os higienistas os 'pais' da psiquiatria brasileira, por faltar, na nossa opinião, comprovação consistente para tal assertiva. Igualmente parece-nos incorreto intitular a obra como História da psiquiatria no Brasil, quando ela refere-se apenas a um episódio dessa história.

${ }^{10}$ Por motivo idêntico, ainda que para época diversa à estudada nesse artigo, Dias (2003, p.97) toma o autor como referência intelectual.

\section{REFERÊNCIAS}

\section{Atos normativos}

\section{BRASIL}

Lei n. 10.216. Dispõe sobre a proteção e os direitos das pessoas portadoras de transtornos mentais e redireciona o modelo assistencial em saúde mental. 6 abr. 2001

BRASIL

Decreto n. 49.974-A. Regulamenta, sob a denominação de Código Nacional de Saúde, a lei 2.132 , de 3 de setembro de 1954, de normas gerais sobre defesa e proteção da saúde. 21 jan. 1961

\section{BRASIL}

Lei n. 1102. Aprova o Plano Salte e dispõe sobre sua execução. 18 maio 1950

\section{BRASIL}

Decreto n. 28.096. Declara de utilidade pública o Instituto Brasileiro de Psicanálise com sede nesta capital. 10 maio 1950

\section{BRASIL}

Decreto n. 22.561. Concede favores fiscais aos estabelecimentos hospitalares que se construírem no Distrito Federal e dá outras providências.7 fev. 1947

BRASIL

Decreto-lei n. 8.550. Autoriza o Ministério da Educação e Saúde a celebrar acordos, visando a intensificação da assistência psiquiátrica no território nacional. 3 jan. 1946

BRASIL

Decreto-lei n. 3.138. Dispõe sobre a prestação de assistência médica, pelos institutos e caixas de aposentadorias e pensões, aos doentes mentais que forem seus segurados ou associados. 24 mar. 1941

BRASIL

Decreto n. 24.559. Dispõe sobre a profilaxia mental, a assistência e proteção à pessoa e aos 
bens dos psicopatas, a fiscalização dos serviços psiquiátricos e dá outras providências. 3 jul. 1934

BRASIL

Decreto n. 5.148. Reorganiza a Assistência a Psicopatas no Distrito Federal. 10 jan. 1927

BRASIL

Decreto n. 4.778. Considera de utilidade pública a Liga Brasileira de Higiene Mental, com sede nesta capital. 27 dez. 1923

BRASIL

Decreto n. 4.665. Considera de utilidade pública a Liga Nacional Contra o Alcoolismo e outras instituições. 24 jan. 1923

BRASIL

Decreto n. 4.294. Estabelece penalidades para os contraventores na venda de cocaína, ópio, morfina e seus derivados; cria um estabelecimento especial para internação dos intoxicados pelo álcool ou substâncias venenosas; estabelece as formas de processo e julgamento e manda abrir os créditos necessários. 6 jul. 1921

\section{BRASIL}

Decreto n. 3.987. Reorganiza os serviços da saúde pública. 2 jan. 1920

BRASIL

Decreto n. 2.861. Aprova as medidas tendentes a impedir os abusos de ópio, da morfina e seus derivados, bem como da cocaína constantes das resoluções aprovadas pela Conferência Internacional do Ópio, realizada em 10 de dezembro de 1911, em Haya. 8 jul. 1914

BRASIL

Decreto n. 8.834. Reorganiza a Assistência a Alienados. 11 jul. 1911

BRASIL

Decreto n. 1.132. Reorganiza a Assistência a Alienados. 22 dez. 1903

BRASIL

Decreto n. 896. Consolida as disposições em vigor relativas aos diferentes serviços da Assistência Médico-Legal de Alienados. 29 jun. 1892

BRASIL

Decreto n. 1.180. Cria no Hospício Nacional de Alienados um Museu Anátomo-Patológico e dá outras providências. 18 dez. 1890

BRASIL

Decreto n. 791. Cria no Hospício Nacional de Alienados uma Escola Profissional de Enfermeiros e Enfermeiras. 27 set. 1890

BRASIL

Decreto n. 508. Aprova o regulamento para a Assistência Médico-Legal de Alienados. 21 jun. 1890
BRASIL

Decreto n. 206. Aprova as instruções a que se refere o decreto número $142 \mathrm{~A}$, de 11 de janeiro último e cria a Assistência Médica e Legal de Alienados. 15 fev. 1890

BRASIL

Decreto n. 142. Desanexa do Hospital da Santa Casa de Misericórdia desta capital o Hospício de Pedro II, que passa a denominar-se Hospício Nacional de Alienados. 11 jan. 1890

\section{REFERÊNCIAS BIBLIOGRÁFICAS}

BERTOLOTE, José Manoel

As origens do conceito de saúde mental. Temas, São Paulo, n.58, p.46-56. 2000

BRANDÃO, João Carlos Teixeira

Elementos fundamentaes de psychiatria clinica e forense. Rio de Janeiro: Leite Ribeiro \& Maurillo. 1918

CANGUILHEM, Georges

O normal e o patológico. Rio de Janeiro: Forense Universitária. 1990

CAPONI, Sandra

Da compaixão à solidariedade: uma genealogia da assistência médica. Rio de Janeiro: Editora Fiocruz. 2000

CASTEL, Robert

A ordem psiquiátrica: a idade de ouro do alienismo. Rio de Janeiro: Graal. 1978

COSTA, Jurandir

História da psiquiatria no Brasil: um corte ideológico. Rio de Janeiro: Xenon. 1989

DIAS, Paula Barros

Arte, loucura e ciência no Brasil: as origens do Museu de Imagens do Inconsciente. Dissertação (Mestrado em História das Ciências da Saúde) Casa de Oswaldo Cruz/Fiocruz, Rio de Janeiro. 2003

ENGEL, Magali

Os delírios da razão: médicos, loucos e hospícios (Rio de Janeiro, 1830-1930). Rio de Janeiro: Ed. Fiocruz. 2001

FIGUEIREDO, Gabriel

Ética e reforma da assistência psiquiátrica no Brasil. Temas, São Paulo, v.31, n.60-61, p.1-14. jan.-dez. 2001

FOUCAULT, Michel

História da loucura na idade clássica. São Paulo: Perspectiva. 1995

FREITAS, Fernando

A história da psiquiatria não contada por Foucault. História, Ciências, Saúde - Manguinhos, Rio de Janeiro, v.11, n.1, p.75-91. jan.-abr. 2004 
GOULD, Stephen Jay Carrie Buck's daughter. In: Gould, Stephen Jay. The Flamingo's smile: reflections in natural history. Reino Unido: Penguin Books, p.306318. 1985

\section{LUZ, Madel Therezinha}

As instituições médicas no Brasil: instituição e estratégia de hegemonia. Rio de Janeiro: Graal. 1986

LUZ, Madel Therezinha Medicina e ordem política brasileira: políticas e instituições de saúde (1850-1930). Rio de Janeiro: Graal. 1982

MACHADO, Roberto et al.

Danação da norma: medicina social e constituição da psiquiatria no Brasil. Rio de Janeiro: Graal. 1978

MOTA, Carlos Guilherme

Ideologia da cultura brasileira (1933-1974). São

Paulo: Editora Ática. 1994

OMS

Organização Mundial da Saúde. Relatório sobre a saúde no mundo: saúde mental - nova concepção, nova esperança. 2001

PAMPLONA, Marco

A revolta era da vacina?. In: Scliar, Moacyr et al. Saúde pública: histórias, políticas e revolta. São Paulo: Scipione. p.64-87 (Coleção Mosaido Ensaios e Documentos). 2002

PATTO, Maria Helena Souza

Estado, ciência e política na Primeira República: a desqualificação dos pobres. Estudos Avançados, São Paulo, v.13, n.35, p.167-198. 1999

PAULIN, Luiz Fernando; TURATO, Egberto Antecedentes da reforma psiquiátrica no Brasil: as contradições dos anos 1970. História,

Ciencias, Saúde - Manguinhos, Rio de Janeiro, v. 11, n.2, p.241-58. maio-ago. 2004

PEREIRA NETO, André

Ser médico no Brasil: o presente no passado. Rio de Janeiro: Ed. Fiocruz. 2001
PORTER, Roy

Madness and its institutions. In: Wear, Andrew (Ed.). Medicine in society: historical essays.

Cambridge: Cambridge University Press. p.277302. 1992

PORTOCARRERO, Vera

Arquivos da loucura: Juliano Moreira e a

descontinuidade histórica da psiquiatria. Rio de Janeiro: Ed. Fiocruz. 2002

\section{RESENDE, Heitor}

Política de saúde mental no Brasil: uma visão histórica. In: Tundis, Silvério A.; Costa, Nilson do Rosário (Org.). Cidadania e loucura: políticas de saúde mental no Brasil. Petrópolis: Vozes. 2000

SILVA, José Afonso da

Curso de direito constitucional positivo. 15. ed. São Paulo: Malheiros. 1998

\section{SKIDMORE, Thomas}

Uma história do Brasil. São Paulo: Paz e Terra.1998

\section{STEPAN, Nancy}

A hora da eugenia: raça, gênero e nação na América Latina. Rio de Janeiro: Editora Fiocruz. 2005

SOUZA, Vanderlei Sebastião de A política biológica como projeto: a 'eugenia negativa' e a construção da nacionalidade na trajetória de Renato Kehl (1917-1932). Dissertação (Mestrado em História das Ciências da Saúde) - Casa de Oswaldo Cruz/Fiocruz, Rio de Janeiro. Disponível em http://

dominiopublico.mec.gov.br/download/texto/ cp009711.pdf. Acesso em: 1 out. 2007. 2006

TERNON, Yves

Le massacre des aliénés. Historia, n.361 bis, p.14-27. Numéro spécial: Médicins SS. 1976

YAHN, Mário

Higiene mental e saúde pública. São Paulo: Edigraf.1955 